\title{
Why Immigrants Leave New Destinations and Where Do They Go? ${ }^{1}$
}

by

\author{
Mary M. Kritz \\ Cornell University
}

Douglas T. Gurak

Cornell University

\author{
Min-Ah Lee \\ Chung-Ang University
}

CES 13-32 June, 2013

The research program of the Center for Economic Studies (CES) produces a wide range of economic analyses to improve the statistical programs of the U.S. Census Bureau. Many of these analyses take the form of CES research papers. The papers have not undergone the review accorded Census Bureau publications and no endorsement should be inferred. Any opinions and conclusions expressed herein are those of the author(s) and do not necessarily represent the views of the U.S. Census Bureau. All results have been reviewed to ensure that no confidential information is disclosed. Republication in whole or part must be cleared with the authors.

To obtain information about the series, see www.census.gov/ces or contact Fariha Kamal, Editor, Discussion Papers, U.S. Census Bureau, Center for Economic Studies 2K132B, 4600 Silver Hill Road, Washington, DC 20233, CES.Papers.List@census.gov. 


\begin{abstract}
Immigrants have a markedly higher likelihood of migrating internally if they live in new destinations. This paper looks at why that pattern occurs and at how immigrants' out-migration to new versus traditional destinations responds to their labor market economic and industrial structure, nativity origins and concentration, geographic region, and 1995 labor market type. Confidential data from the 2000 and 1990 decennial censuses are used for the analysis. Metropolitan and non-metropolitan areas are categorized into 741 local labor markets and classified as new or traditional based on their nativity concentrations of immigrants from the largest Asian, Caribbean and Latin American origins. The analysis showed that immigrants were less likely to migrate to new destinations if they lived in areas of higher nativity concentration, foreign-born population growth, and wages but more likely to make that move if they were professionals, agricultural or blue collar workers, highly educated, fluent in English, and lived in other new destinations. While most immigrants are more likely to migrate to new rather than traditional destinations that outcome differs sharply for immigrants from different origins and for some immigrants, particularly those from the Caribbean, the dispersal process to new destinations has barely started.
\end{abstract}

\footnotetext{
${ }^{i}$ The research in this paper was conducted at the New York Census Research Data Center, Cornell University, while the authors were Special Sworn Status researchers of the U.S. Census Bureau. Any opinions and conclusions expressed herein are those of the authors and do not necessarily reflect the views of the Census Bureau. All results have been reviewed to ensure that no confidential data are disclosed. Support from NSF (ITR-0427889) for this research is gratefully acknowledged. We also gratefully acknowledge grant support from the Russell Sage Foundation (RSF \#88-07-03) and the Polson Institute for Global Development, Cornell University.
} 


\section{Introduction}

Increasing numbers of U.S. immigrants are moving to new destination places rather than to Los Angeles, New York, Miami, Chicago or other large metropolitan areas where contemporary immigrants have traditionally settled (Frey, 2005; Goździak and Martin, 2005; Lichter and Johnson, 2006; Massey and Capoferro, 2008; Singer, 2004). As recently as 1990, nearly half (47 percent) of all immigrants lived in California or New York but only 41 percent lived in those states in 2000 and 37 percent in 2009. ${ }^{\mathrm{i}}$ Similar declines occurred in immigrant's top two metropolitan settlement areas - Los Angeles and New York - where 27 percent of all foreign born lived in 1990 but only 18 percent in 2009. In contrast, foreign-born populations soared between 1990 and 2000 in states that had relatively few immigrants, growing by over 400 percent in North Carolina, Georgia and Arkansas and by over 300 percent in Tennessee, Nevada, South Carolina, Kentucky, and Alabama. These trends are well documented for the total foreign born as well as for immigrants from Latin America, Mexico and Asia (Bump, Lowell and Pettersen, 2005; Camarota and Keeley, 2001; Donato, et al., 2007; Durand, Massey and Capoferro, 2005; Ellis and Goodwin-White, 2006; Frey and Liaw, 1999; Funkhouser, 2000;

Kandel and Cromartie, 2004; Lichter and Johnson, 2006; Lichter and Johnson, 2009; Massey and Capoferro, 2008; Parrado and Kandel, 2008; Singer, 2004; Suro and Singer, 2002; Tienda and Wilson, 1992). In addition, a growing body of case studies shed light on the implications of new destination settlement for immigrants’ labor force participation, education profiles, family structures, political participation, and intergroup relations (Davey, 2007; Fischer, 2010;

Goździak and Martin, 2005; Kandel and Parrado, 2004; Kandel and Parrado, 2005; Massey, 2008; Millard and Chapa, 2004; Odem and Lacy, 2009; Parrado and Kandel, 2008; Smith and Furuseth, 2006; Stamps and Bohon, 2006; Winders, 2005; Zúñíga and Hernández-León, 2005). 
Previous studies provide a wealth of insights into the factors underlying foreign-born settlements in new destinations but these geographic shifts are relatively recent and nationallevel data are limited on how geographic dispersion varies for immigrants from different national origins. Further research is needed on a host of issues. One research issue that has not been addressed is whether immigrants who are moving to new destinations are likely to develop longterm settlements in those places or whether they only stay in those places for a few years before returning to traditional metropolitan areas where most immigrants continue to live. Alternatively given that immigrants' experiences in new destinations are relatively recent, many of them may like the life styles associated with new destinations because they offer them better economic and social opportunities. A recent study by Kritz, Gurak and Lee (2011) found that immigrants who lived in new destinations were more likely to leave those places than ones living in traditional areas. While that study suggests that there may be a great deal of churning in new destinations, it did not identify how immigrants' individual and contextual characteristics shaped those choices nor where immigrants went who did leave new destinations.

These issues are examined in this study because concerns have been raised regarding whether today's immigrants who come mainly from developing countries with different cultural and historical heritages will experience different incorporation and assimilation trajectories than European immigrants did in the last century. It has been argued, for instance, that the "new" immigrants who come from Asia, the Caribbean and Latin America experience discrimination in jobs and housing and downward mobility due to their racial and cultural distinctiveness from native whites (Massey, 1995; Massey and Sánchez, 2009; Portes and Rumbaut, 2001; Portes and Zhou, 1993; Zhou, 1999). While we do not address that issue directly in the paper, the dispersal of immigrants to new destinations suggests that they are not hesitant to move to parts of the 
country where they have few compatriots and where they are unlikely to find bilingual community-based organizations that can assist them in their integration efforts.

The paper draws on Confidential Use Microdata Samples (CUMS) from the 2000 and 1990 decennial censuses to address three specific questions: whether immigrants who live in new destinations are more likely to out-migrate to other new destinations or to traditional ones; how immigrants' individual and labor market context shape out-migration; and how patterns differ for immigrants from the largest Asian, Caribbean, and Latin American national origin groups. Because previous research indicates that immigrants' individual characteristics are strong determinants of their migration decisions (Bartel and Koch, 1991; Kritz and Nogle, 1994), the analysis focuses more on the economic, geographic and nativity contexts where immigrants lived in 1995, including whether they lived in a new versus a traditional area, the region of the country, and labor market economic and industrial structure. In addition, the analysis controls for immigrant’s national origins and compatriot availability. Because CUMS files have more geographic information and larger sample sizes than do PUMS files, they permit researchers to look at these patterns in greater details for immigrants from different national origins and in a larger number of geographic contexts than previous studies. The CUMS are not constrained to fixed geographies as PUMS files are, which means that researchers can build geographic units that correspond to local labor markets and that have comparable boundaries across time. In addition to their much greater geographical detail and coverage of the entire country at different time points, confidential census files have more than three times the number of sample cases as the largest public use files, which permit us to develop origin-specific measures in different labor markets in order to control for heterogeneity within the foreign-born population. 


\section{Factors Underlying Foreign-Born Internal Migration}

Research on the internal migration of immigrants in the USA indicates that they are as likely to migrate internally as natives and that their migration decisions respond to human capital in much the same way as those of natives do. Both populations, native and foreign born, are more likely to migrate internally if they are educated and male but less likely to do so as they age (Belanger and Rogers, 1994,Bartel, 1991 \#193; Ellis and Goodwin-White, 2006; Kritz, Gurak and Lee, 2011; Kritz and Nogle, 1994). There are also individual characteristics associated with the immigration process that affect immigrants’ migration propensities. Immigrants, for instance, are more likely to migrate if they have greater English language fluency but less likely to do so the longer they have been in the country; it is also the case that immigrants from some national origins are more likely to migrate than others but are deterred from doing so if they live in places where large numbers of their compatriots live (Bartel and Koch, 1991; Fang and Brown, 1999; Frey and Liaw, 2005; Gurak and Kritz, 2000; Kritz and Nogle, 1994). Other studies have found that immigrants moving internally tend to go to destinations where co-ethnics live just as newly arriving immigrants do (Leach and Bean, 2008; Nogle, 1997).

Except for the finding that immigrants’ migration decisions are conditioned by nativity concentrations, little attention has been given to the types of places that immigrants are more likely to leave or where they go if they do migrate internally. Heer (2002) addressed the first issue, claiming that immigrants would start to leave California if large numbers of unskilled workers from Mexico continued to arrive because that would lead to increased job competition with unskilled workers already there and drive down wages. Light (2006) examined whether Heer's thesis accurately described what happened in the Los Angeles metropolitan area in the 1990s and found that heavy immigration from Mexico and elsewhere had indeed made it more 
difficult for unskilled workers, native- and foreign-born, to find jobs and housing, which correlated with increasing unemployment, crowding in residential housing and slum growth. To resolve these growing poverty problems and maintain residential quality of life, homeowners and social justice advocates encouraged local governments to implement housing and other policies that were directed toward improving living standards. Light (2006) found that the unintended consequence of those policies was a limitation of job growth in the ethnic economy and deflection of immigrants away from Los Angeles to other parts of the country.

Studies of immigrants' internal migration dynamics have yet to address the question of where they go and, in particular, which ones are moving to traditional versus new destinations. Most of the studies have focused on the characteristics of new destinations that attract immigrants (Donato, et al., 2007) or at how labor market restructuring has increased demand for unskilled workers in the South and Midwest, the two regions where foreign-born populations have grown most rapidly (Brown, Lobao and Digiacinto, 1999). The industrial restructuring studies hold that global competition in manufacturing not only encourages employers to shift jobs abroad, a trend widely acknowledged, but also to move operations to lower wage areas within the USA (Hirschman and Massey, 2008, 8). For instance, many employers have moved manufacturing jobs out of high wage states in the Northeast and West, where immigrants have traditionally settled, to states in the South and elsewhere that have right-to-work rules and lower wages. Another corporate strategy is to outsource production components to labor subcontractors who, in turn, hire immigrants because they are willing to work for lower wages than natives. As a result, new jobs in food processing, agriculture, manufacturing and other industries have increased in the South and Great Plains, while higher paying union jobs in the Northeast have declined. These labor market shifts correlate with the increasing foreign-born settlement in the 
South that Massey and Capoferro (2008) document. Kandel and Parrado (2005; Parrado and Kandel, 2008) have described how industrial changes in agricultural, food and meat processing industries affect worker demand and attract low-skilled immigrants to non-metropolitan areas in the Southeast and upper Midwest. Broadway and Ward (1990) found that many food processing firms relocated from the North Central region to the South to take advantage of non-unionized, low wage labor.

An abundant economic literature documents that workers do indeed move in response to shifting economic opportunities and that they are more likely to leave areas that have lower wages and higher unemployment rates and move to ones with better economic conditions (Brown, Lobao and Digiacinto, 1999; Greenwood, 1981; Greenwood, 1997; Smith and Edmonston, 1997). While studies of the determinants of native-born internal migration have found broad support for neoclassical economic tenets, most immigrant studies have not looked at economic indicators and findings are mixed for those that have. Gurak and Kritz (2000), for instance, found that immigrants were less likely to leave states with higher employment growth and employment shares in manufacturing but Ellis and Goodwin-White (2006) did not find comparable effects. Bartel and Koch (1991) also did not find any association between foreignborn internal migration and unemployment rates and wages in metropolitan areas. Leach and Bean (2008) found that Mexican men who migrated internally were attracted to states that had higher employment shares in service and construction industries. Ley (2007) found that net outmigration from Toronto and Sydney was greater when unemployment was low, arguing that this counterintuitive finding may have occurred because housing prices usually rise in growing economies. These findings indicate that further study is needed before definitive statements can be made about how economic conditions shape immigrants’ migration decisions. 
New destination studies have focused largely on unskilled immigrants in new destinations although internal migration research shows that skilled immigrants typically are more likely to migrate internally than unskilled ones (Bartel and Koch, 1991; Gurak and Kritz, 2000; Kritz, Gurak and Lee, 2011; Kritz and Nogle, 1994). According to Moretti (2012) the spatial locations of jobs likely to attract skilled versus unskilled workers differ. Given that the U.S. immigrant population has a bifurcated skill profile with comparable numbers of skilled and unskilled immigrants, it is important to look at how immigrants’ skill profiles shape their internal migrations to new versus traditional destinations given that settlement patterns also differ across origin groups. While unskilled immigrants typically work in construction, manufacturing and service sectors, skilled immigrants work in health, education, or other professional and high technology industries that have also been restructured in recent decades. Health maintenance organizations (HMOs), for instance, have extended their service networks and set up satellite health clinics throughout the country, including rural areas, out of which they provide preventive and curative services while channeling patients needing acute care to medical centers in metropolitan areas. In order to contain costs, many HMOs hire foreign-born medical personnel to staff satellite clinics. Foreign-born doctors and health workers are eligible for exchange visitor visas if they agree to work for a few years in areas deemed to be experiencing worker shortages. ${ }^{\mathrm{ii}}$ Comparable changes have occurred in higher education. Most states have increased their number of universities, community colleges and technical schools in order to give rural and small town residents increased access to higher education and technical training. Growing numbers of teachers, instructors and others who work in science, technology, engineering and mathematics (STEM) fields have immigrant backgrounds and many of them work at colleges and universities in new destination areas. 
While spatial differentials in economic climate and industrial restructuring create incentives for people to migrate internally, there are also social forces that deter them from moving. Several studies show that immigrants are less likely to migrate if they live in places where large numbers of their compatriots reside (Bartel and Koch, 1991; Ellis and GoodwinWhite, 2006; Frey and Liaw, 2006; Kritz and Nogle, 1994). Haug (2008) dubs this the affinity hypothesis and others call it the cultural constraint hypothesis (Frey and Liaw, 2006) or nativity concentration effect (Rebhun, 2006). Because census data lack information on immigrants' social networks and affinities, we measure this social dimension based on nativity concentrations but recognize that it is only a proxy for social relationships in co-ethnic communities that discourage immigrants from leaving those places. Explanations regarding why nativity or ethnic concentrations deter out-migration tend to focus on their economic benefits for residents, particularly the help that immigrants receive from co-ethnics in locating jobs, housing, and community services (Portes, 1995). Other research shows that co-ethnic communities have beneficial impacts on immigrants' overall wellbeing and health (Lee and Ferraro, 2007). In addition, immigrants may prefer to live in co-ethnic communities because those places offer them cultural and institutional resources that they are unlikely to find in dispersed communities (Breton, 1964; Logan, Alba and Zhang, 2002). Nativity affinities may stem from the high degree of selectivity that characterizes U.S. immigrants and the presence of strong cumulative causation ties among them (Massey, et al., 1987; Van Hook and Glick, 2007). Origin country differences in modes of legal entry, skill profiles and economic strategies as well as in cultural, economic and social heritages reinforce and strengthen social ties among immigrants. Distinctive national origin settlement patterns within the USA also strengthen immigrants' social ties and underlie origin group differences in internal migration rates and destination choices among immigrants 
who do resettle (Kritz and Gurak, 2004; Lieberson and Waters, 1987; Waters and Lieberson, 1988).

\section{Study Directions and Hypotheses}

Given the dearth of demographic research on the determinants of foreign-born internal migration to and from new destinations, this is largely an exploratory study that seeks to establish levels of out-migration to new and traditional destinations and to identify individual and contextual correlates of those flows. The analytic question addressed is whether immigrants in the largest "new” immigrant groups were more likely to migrate from 1995 to 2000 if they lived in new versus traditional areas and, if they did migrate, whether they migrated to new or traditional destinations. Recent immigrants who arrived between 1995 and 2000 are excluded from the analysis because they did not have a U.S. residence place in 1995 and thus were not exposed to the measurable risk of internal migration. The immigrants included in the sample come from Asian, Caribbean and Latin American countries that only started to send large numbers of immigrants to the USA in recent decades. Overall, 72 percent of all U.S. foreign born were from "new” origin countries in 2000. Although migration to new destinations alone does not indicate whether immigrants are assimilating spatially, the fact that immigrants have fewer compatriots in those areas means that large nativity concentrations cannot be formed and that there will be greater opportunity for interactions with natives than there would be in spatially concentrated communities in large metropolitan areas.

The main explanatory measure, 1995 residence in a new destination, is expected to be positively related to both out-migration to new and traditional destinations but also to depend on immigrants’ individual characteristics as well as their geographic, economic, and nativity 
contexts and origins. Once an immigrant migrates to a new destination one might expect that the gravitational pull of traditional destinations will have been weakened and that further moves would tend to be to other new destinations. While the analysis looks at that issue, it is reasonable to expect that the relative dearth of compatriots in new destinations will be important to many immigrants and, therefore, that many of them will leave those places for traditional destinations because they value ethnic affinities.

Immigrants’ geographic region of residence is expected to be related to migration outcomes because economic conditions, growth and industrial restructuring differ across states and regions (Brown, Lobao and Digiacinto, 1999). Given that many of the new destinations that attracted immigrants in the 1990s are located in the South and Midwest, immigrants living in those regions should be less likely to migrate to traditional destinations both because the economic conditions that initially led them to settle there remained operative in 2000 and because migrations from many places in the South or Midwest to traditional destinations such as Los Angeles or New York involve longer distance moves, which in general are less common. At the same time, immigrants in the South and Midwest should be more likely to out-migrate to new destinations because their settlements in those regions are relatively recent and remain exploratory. We do not look directly at Heer's thesis that California immigrants may be leaving that state but do so indirectly by examining how residence in the West affects internal migration (Heer, 2002).

Although we expect to find relationships similar to those of previous studies for immigrants' human capital and assimilation characteristics, some individual measures may have different effects on out-migration to new versus traditional destinations. For instance, while college-educated immigrants should be more likely to migrate internally, we expect that they 
may be more likely to migrate to traditional destinations because job opportunities for the college educated tend to be more abundant in the large metropolises that comprise the set of traditional areas where most immigrants live (Appendix A). It may also be easier for highly educated immigrants to relocate to their group's traditional settlement areas than it is for immigrants with less education because they are more likely to have skills that are tradable in the market place or economic resources that enable them to start ethnic enterprises. Immigrants who have a good command of English also have increased choices and may choose new destinations because they can readily participate in work and community activities in places that have relatively few bilingual speakers and services. We expect immigrants to be less likely to migrate internally if they came to the USA at older ages and lived in the country longer. Immigrants who arrive at older ages often come to join family members and thus they tend to settle in traditional areas where most immigrants live. That same reasoning applies to immigrants who have been in the USA longer - as people put down roots in an area, immigrants as well as natives become less likely to migrate. While foreign-born men are expected to be more likely than women to migrate internally, we do not have a basis for expecting those rates to differ for out-migration to new versus traditional destination. Research indicates that family formation and change are important determinants of migration (Carlson, 1985; Landale, 1994) but because census data are crosssectional, it is not possible to determine whether marital status changed before or after migration. We do include one family measure in our models, namely immigrant's never married status, and expect it to be positively related to out-migration to traditional destinations but negatively related to out-migration to new destinations.

Including measures for labor market wages and industrial structures as well as immigrants' occupations allow us to assess how immigrants' migration decisions respond to 
economic factors. Labor market wages are expected to deter out-migration to both traditional and new destinations because it is advantageous for workers to stay in areas with robust economies but higher wages should be a stronger deterrent of out-migration to new destinations because immigrants have less information about employment prospects in dispersed areas. On the other hand, immigrants working in labor markets with high professional industry shares should be more likely to migrate internally because many of them will have graduate or professional training which increases their employment prospects in different areas. It is less clear how employment shares in other industrial sectors will shape out-migration but the importance of four sectors are examined, namely the percentages of the labor force in different geographic areas that are employed in manufacturing, residential growth, recreational and personal services, and agriculture. Immigrants in these sectors would have less education and opportunities than workers in professional industries, which suggest that they would be less likely to migrate internally. They may also be less likely to leave labor markets with high shares in manufacturing, residential growth, and recreational and personal services because high employment shares suggest that there may be multiple job prospects in those industries. On the other hand, immigrants who live in areas with high agricultural employment should be more likely to migrate because those areas have rural characteristics and immigrants have very few compatriots and immigrant-support services available to them in rural areas.

Nativity context is an important determinant of immigrants' internal migration and we expect to replicate that finding in this study (Bartel and Koch, 1991; Kritz and Nogle, 1994). Since ethnic affinity ties should be strongest among first-generation immigrants, we expect to find that immigrants from most of the "new" origin countries will be more likely to migrate to traditional destinations since those are the areas where most of their compatriots live and less 
likely to move to new destinations. However, regardless of whether they live in traditional or new destinations, immigrants will be less likely to leave areas of higher nativity concentration for their group and where foreign-born growth was higher between 1990 and 2000. The foreignborn change measure is considered a proxy for unmeasured labor market dynamics and social networking ties among immigrants from different national origins.

\section{Data and Measures}

In order to evaluate how immigrants' individual and context characteristics shape their migration decisions, it is important to examine relationships in a larger number of labor markets and for more origin groups than previous studies have done. Ideally data should have sufficient geographic detail to permit identification of local labor markets and this necessarily requires large enough sample sizes to produce robust statistics for immigrants by national origin in different areas. PUMS files do not have the requisite geographic detail for such a study and while they do have a relatively large number of foreign-born cases, CUMS files are a 16 percent population sample, which is more than three times the size of the largest PUMS (Donato, et al., 2007). This is an important advantage because immigrants are a relatively small population subgroup (approximately 11 percent of the population in 2000) and only about ten percent of them migrated internally between 1995 and 2000. Identifying new destinations for immigrants from different national origins is further complicated given that these are places where relatively few immigrants live. For this analysis we look at out-migration patterns from 741 geographic contexts (described below) that cover the entire USA and have identical boundaries for 1990, 1995 and 2000. Many of these new destination places are small metropolitan or rural areas for which no individual-level information on immigrants is available in PUMS files, in accordance 
with government confidentiality rules. CUMS files, on the other hand, do have detailed data on immigrants in metropolitan and non-metropolitan areas throughout the country. Researchers can only access CUMS files at one of the Bureau's secure data centers; in addition, summary statistics and analyses prepared at those centers need to be approved by the Bureau's Disclosure Review Board to assure that they comply with privacy rules (Donato, et al., 2007). Although ideally it would be good to use data for a more recent period, the latest five-year CUMS for the five-year American Community Survey (ACS) has significantly fewer foreignborn cases than the 2000 CUMS. In addition to having more cases, the 2000 CUMS allows us to establish a baseline profile of immigrant settlement in new destinations, a task that has not been done and that will be more difficult to do in the years ahead given the ACS's reduced sample size and shift from a five-year to a one-year migration window. ${ }^{\text {iii }}$

The analysis sample includes foreign-born non-group quartered adults from 24 national origins that each had a total population size, all ages, of at least 200,000 immigrants in 2000. While several European senders and Japan met this size criterion, they are not included in the sample because their U.S. immigrations started more than a century ago, which means that they have well-established settlements spread throughout the country in contrast to the "new" immigrants from Asia, the Caribbean, and Latin America whose arrivals in large numbers only started after passage of the Immigration and Nationality Act of 1965 . No African country met the 200,000 threshold. The sample includes 11 groups from Latin America (Mexicans, Cubans, Salvadorans, Dominicans, Colombians, Guatemalans, Ecuadorans, Hondurans, Peruvians, Nicaraguans, and Brazilians), 9 from Asia (Filipinos, Chinese, Indians, Vietnamese, Koreans, Taiwanese, Iranians, Pakistanis, and Laotians), 3 from the non-Hispanic Caribbean (Jamaica, Haiti, and Guyana), and Canadians. The latter are included because non-Hispanic whites cannot 
be used as the reference population given that census data lack immigration indicators for natives. Therefore in order to use indicators that have been shown to be important for foreignborn internal migrations, including year of entry, naturalization, and English language skills, the study population was constrained to immigrants; Canadians are used as the reference group because they are an immigrant group that has an ethnic composition and settlement patterns that approximate those of natives. Immigrants from these 24 origins constituted 72 percent of the total foreign-born population of the United States in 2000. The study sample consists of all immigrants aged 25 to 29 from these 24 origins who resided in the USA in 1995. The unweighted sample size was $1,625,958$. The sample is limited to immigrants aged 25 to 59 in order to minimize the likelihood that their migrations responded to higher education completion or retirement.

\subsection{Labor Market Geographic Units and Identification of New Destinations}

The geographic units consist of 741 labor markets that cover the entire country and have identical boundaries across time. To construct them, we built on a set of geographic units that Tolbert (2006; 1996) developed using cluster analysis to identify commuting patterns between contiguous counties in 1990. They are composed of counties or county equivalents that are relatively small and homogeneous. Ones with the largest populations approximate standard metropolitan statistical areas (SMSAs) while others in non-metropolitan areas have smaller populations that cover larger territories. Because the number of geographic units is relatively large, it is possible to examine how economic and nativity conditions in different types of labor markets shape out-migration. Previous national-level new destination studies have had too few geographic units to do that because they have been based on states or metropolitan areas. 
Although migration theories focus on local labor market conditions as explanatory factors underlying internal migration, lack of geographic detail and limited sample size in public use files make that difficult to do.

Migration is defined as a move from one labor market to another between 1995 and 2000 that covered a distance of at least 50 miles. The dependent variable is a three category measure that differentiates between out-migrants to new destinations, out-migrants to traditional destinations, and non-migrants (reference group). For each national origin group, the traditional destination category includes the top 10 labor markets where each group was settled in 1995 and the new destination category includes the remaining 731 units. This classification method means that each of the 24 national origin groups has a different set of new and traditional destinations. Although most immigrant groups have Los Angeles, New York, Washington DC/Northern Virginia, or Newark/Northern New Jersey as one of their traditional destinations (see Appendix A) and San Francisco, Chicago, Miami, Boston, Houston, and San Jose are among the traditional places for several groups, some groups had one or more traditional destinations that were not traditional areas for others. Laotians, for example, were the only group that had Modesto, Milwaukee, and Chico/Butte as traditional destinations. While other groups may also have some nationals settled in those places, for them the place would be a new rather than a traditional destination. The percentages of the population from different origins that lived in new destinations ranged from a low of 7.2 percent for Dominicans to a high of 63.4 percent for Canadians (See Figure 1 and Table 1). The fact that Canadians are more dispersed than any of the "new" immigrant groups further justifies using them as the reference.

Given that several origin groups have highly concentrated settlement patterns and small percentages of their populations in new destinations argues for the use of a small number of areas 
in the traditional destination category in order to assure that there will be sufficient cases in a large number of new destinations for all origin groups. ${ }^{\text {iv }}$ That condition is important for carrying out this type of analysis given that origin descriptive statistics and probabilities are based on group tendencies. We did do sensitivity analysis for alternative new destination measures, including for Mexicans alone given that they constitute about 40 percent of the study sample and have larger numbers in most labor markets than other groups but findings were comparable. Therefore, the top ten cut point was used to maximize numbers and percentages for the smaller origin groups in both categories. Given 741 labor markets and 24 origin groups, there are 17,784 possible place-group combinations. However, many labor markets only have immigrants from a few of the larger or more dispersed groups, such as Mexicans and Canadians. Smaller groups, in contrast, are spread across fewer labor markets and thus the actual number of group-specific labor market areas in the analysis is 10,788 .

Our new destination category differs from ones used in most new destination studies in that it is based on the group-specific settlement patterns of immigrants from 24 national origins in 741 labor markets located across the country. Most previous studies have classified states, metropolitan areas or counties as new destinations based on the composition and growth patterns of the total foreign born or pan-ethnic groupings such as Hispanics (Donato, et al., 2007; Fischer and Tienda, 2006; Kandel and Parrado, 2005; Lichter and Johnson, 2009; Massey and Capoferro, 2008; Singer, 2004; Suro and Singer, 2002). This is problematic, however, because the resulting classifications are heavily weighted by Mexicans, the largest foreign-born and Hispanic group. In 2000, for instance, almost a third of the total foreign born was of Mexican origin. Since Mexicans have a more dispersed settlement pattern than other origin groups (see Figure 1), this means that many of the new destinations identified in previous studies are places where most 
immigrants are Mexicans. Ultimately whether it is appropriate to use group-specific or total foreign-born measures depends on the study question. For the question addressed here - which immigrants migrate internally and where do they go - it is important to control for origin-group heterogeneity given previous study findings which show sharp group differences in those outcomes. There are other study questions, however, such as ones focused on foreign-born impacts on new destination employment structures, housing markets or schools, for which it would be less important to take immigrant's national origins into account.

\subsection{Covariate Measurement}

For modeling purposes, dummy variables specify whether immigrants are male, never married or naturalized citizens. Additional dummies specify immigrant's education level (college graduate or more, high school graduate or some college, and less than high graduate=referent); English language proficiency (speaks English only or very well, speaks English well, or speaks no English or less than well=referent); and region of residence in 1995 (West; South; Midwest; Northeast=referent). Rather than using a direct measure of age, we disaggregate age into its two additive components - immigrant's age at U.S. entry and number of years since arrival - because both dimensions are immigration-related and can be evaluated as assimilation indicators. They are measured continuously. Immigrants who arrive at older ages are less likely to be fluent in English, naturalized citizens or live in dispersed areas while those that arrive as children or young adults receive part or all of their education in the USA and are more highly assimilated. The second age measure, number of years since arrival, also correlates positively with assimilation measures, including English language fluency, naturalization status and home ownership but not as strongly as age at arrival does. To capture non-linear effects of age, we include a quadratic term for number of years since arrival. 
In addition to using dummy variables to specify immigrant's country of origin, we include two other nativity context measures, namely: each origin group's size in each labor market in 1995 and change in the total foreign-born population from 1990 to 2000. Both are continuous measures and logged to correct for skewness. Economic context is measured with continuous indicators based on 1990 labor market wages and industrial structure. The wage measure was calculated for native-born fulltime workers who spent 45 or more weeks in the labor force in the year prior to the census (1989). It was adjusted for cost-of-living change in the 1990s and logged to correct for skewness. Five industry measures specify the percentages of employed workers in each labor market who worked in the professional sector, residential and retail sector, recreation and personal services, manufacturing sector, or agriculture and food processing industries. These industrial categories were selected because they employ large numbers of immigrants and are not highly correlated with each other. ${ }^{\mathrm{v}}$

Immigrants' economic status is evaluated further by five dummy variables that specify immigrant's occupational status in 2000, namely whether they worked in a health, STEM (science, technology, engineering or mathematics), or other professional occupations, or in agriculture, or blue collar occupations. Although these are occupations that immigrants held in 2000, we assume that they were relatively stable for the five-year time frame of the study and include them because they provide insights into the work that immigrants do in new destinations. Three of the occupations - health, STEM, and other professional - require years of training and thus are likely to be ones that immigrants held before they migrated rather than ones they entered afterwards. While that is less likely to be the case for agriculture and blue collar jobs, those occupations too are relatively specialized and included because they are often mentioned as ones that attract immigrants to new destinations (Leach and Bean, 2008; Millard and Chapa, 2004). 
We also estimated models without these occupation measures and found that omitting them had little effect on other model covariates. Means for model covariates are available in Appendix B for the total sample and for immigrants who resided in new and traditional destinations in 1995.

\section{Accounting for Internal Migration Differentials to New versus Traditional Destinations}

Figure 2 shows the sharp differences in immigrants’ migration patterns to and from new and traditional destinations that this paper seeks to explain (see Table 1 for migration statistics). Overall 10.4 percent of immigrants migrated internally between 1995 and 2000. However, immigrants were more likely to migrate if they lived in new destinations, 16.9 percent left those areas and 7.6 percent left traditional areas. Migration rates also varied by destination choices immigrants had higher rates of out-migration to new destinations than to traditional ones, 6.5 versus 3.9 percent, but if they lived in new destinations, 10.9 percent moved to other new destinations versus 6.0 percent to traditional destinations (Figure 2). Although immigrants living in traditional areas were less likely to migrate, most of those who did selected new destinations. These statistics indicate that immigrants' settlement patterns are changing but also suggest that immigrants may be exploring different non-traditional places. While new destinations were attracting immigrants from elsewhere in the country in the second half of the 1990s, they were also repelling them at relatively high rates.

It is important to recognize that although immigrants have higher rates of out-migration from new destinations that finding is not inconsistent with research findings which show that foreignborn populations are increasing in areas throughout the country where few have previously located. It is also the case that immigrants from some origins have much higher rates of outmigration from new destinations than others (see Table 1). From 1995 to 2000, over a quarter of 
immigrants from five Asian origins - China, India, Taiwan, Pakistan and Korea -left new destinations but only 12 percent of Mexicans. Two refugee groups - Vietnamese and Laotians had relatively low out-migration rates from new destinations but over 20 percent of Dominicans, Brazilians, Colombians, Cubans and Haitians left those areas. While the statistics in Table 1 support the findings by Kritz, Gurak and Lee (2011) that immigrants are twice as likely to migrate internally if they live in new versus traditional areas, Chinese immigrants were more than four times more likely to do so as their compatriots in traditional destinations, and Dominicans, Taiwanese, Ecuadorians, Cubans, Iranians, and Guyanese were three times more likely to move. Laotians were about as likely to leave both types of areas. These findings suggest several possibilities. For instance the high rates of out-migration for the five Asian groups could be related to their higher education and skill profiles while the lower rates for refugee groups may stem from their initial settlement by churches and refugee placement agencies in dispersed locations which gives them opportunities to build up information and contacts in those places which continue to draw them back after they out-migrate to other areas. On the other hand, the relatively low out-migration tendencies of Mexicans and Central Americans from new destinations could be related both to their lower education levels and tendency to work in low wage niches in agriculture and food processing in those parts.

Multinomial logistic regression is used to determine how immigrant's individual characteristics, national origins, settlement locations, and labor market conditions shape their internal migration risks and destinations. In order to obtain standard errors that are corrected for immigrants clustering tendencies in local labor markets, models were estimated using Stata's robust cluster option. A baseline model that had only the main explanatory measure, 1995 residence in a new destination, produced zero-order relative risk ratios of 2.24 and 2.63 for out- 
migration to traditional and new destinations, respectively (not shown). While Model 1, Table 2, indicates that immigrant's individual characteristics attenuated the zero-order difference in outmigration to new versus traditional destinations, they did not account for immigrants increased risks of out-migration from new destinations - immigrants still had relative risks of outmigration from new destinations to both destinations that were 2.2 times higher than from traditional destinations.

The individual characteristics in the model have relationships to migration that are consistent with research expectations and previous studies. Immigrant men were significantly more likely to migrate internally than women as were immigrants with more education and who spoke English only or very well. However, naturalized immigrants were less likely to migrate internally as were immigrants who arrived in the country at older ages. Longer durations in the USA also reduced the risk of migration to new destinations but not to traditional ones and duration effects increase overtime (see squared term for years in USA). The effects of some covariates vary by destination choice. For instance, while never married immigrants were significantly less likely to migrate to new destinations, that measure was not significant for migration to traditional areas. College graduates were more likely to migrate, as expected, especially to traditional destinations - their relative risks of going to traditional and new destinations were 2.4 and 1.7 , respectively. Compared to immigrants living in the Northeast, immigrants in other regions had increased risks of migration to new destinations but only those in the South also differed significantly in outmigration to traditional destinations. Southern immigrants had 23 percent lower odds of migration to traditional destinations but 35 percent higher ones to new destinations. Immigrants in the West and Midwest also had increased relative risks of migration to new destinations. 
The work that immigrants do provides further insights into their internal migration choices. Occupation relative risk ratios were significantly higher for immigrants in professional fields (health, STEM, other professionals) than they were for occupations requiring less education but their magnitude varied by destination type. While health workers had increased odds of migration to new destinations (57 percent), they only had slightly higher odds of migration to traditional destinations. STEM workers, on the other hand, were more likely to migrate to traditional destinations (69 percent) but were almost as likely to go to new destinations (48 percent). "Other professionals,” a category which includes professionals other than health or STEM workers, also had increased migration odds but their choices did not vary by destination type. We expected to find that professionals would have higher migration odds than other immigrants given that they have skills sought after by technology and innovation industries but it was nonetheless surprising to see the importance of those occupations. In contrast, immigrants working in occupations where education levels are lower - agriculture/food processing and blue collar - had reduced odds of migration to traditional destinations but a weak tendency toward migration to new destinations. This tendency, however, was only significant for blue collar occupations. In a model estimated without controls for immigrant's geographic region, the relative risk ratio for agriculture/food processing occupations was positive and significant, which suggests that occupation relationships differ across geographic regions (model not shown). The relative risk ratio for blue collar occupations was also stronger in that model. These occupation relationships are robust and hold up in the next two sets of models.

The second model in Table 2 assesses how immigrants' migration decisions respond to economic conditions by adding indicators for local labor market wages and industrial structure. That model shows that immigrants had significantly reduced odds of migration if they lived in 
labor markets with higher wages. Each logged unit change in the wage measure reduced the relative risk of migrating to traditional versus new destinations by 63 and 77 percent, respectively. Given that labor market wage is a continuous measure, this finding indicates that wages had a very strong effect on migration; indeed a comparison of the magnitude of that measure's unit change compared to those of other covariates indicates that it has the strongest effect. In addition, labor markets that had higher percentages employed in the professional sector produced more out-migrants - immigrants in those places had relative migration risks that were about 40 percent higher. Although it may appear counterintuitive that immigrants have higher odds of out-migration from places that have industrial structures that fit their occupation profiles, migration research has long shown that migration flows generate counter flows. However, the only other significant industrial sector measure was employment share in agriculture immigrants were more likely to leave agricultural areas, which suggest that they may not find jobs in that sector or in rural areas attractive.

Controlling for immigrants' labor market context did not change most of the individual relationships to internal migration described above but did attenuate the increased tendency that immigrants left new destinations although immigrants in those areas still had migration risks that were about 65 percent higher than immigrants in traditional areas. Some change did occur in the relative risk ratios for geographic regions, which is not surprising given that economic restructuring has differentially impacted regions and states in recent decades. Indeed Model 2 shows that after controlling for economic context, there no longer was a significant difference between immigrants in the Northeast, West, and South in out-migration to new destinations although immigrants in the Midwest remained significantly more likely to migrate to new destinations. 
The third model controls for nativity context conditions in immigrant's 1995 place of residence, by adding measures that specify each group's nativity concentration and the percentage change in the total foreign-born population from 1990 to 2000. Dummy variables were also included in that model to control for immigrant's country of origin but the coefficients are not shown in Table 2. The nativity model indicates that labor markets that scored high on nativity concentration and foreign-born growth repelled fewer immigrants. If immigrants lived in labor markets with growing foreign-born populations, their migration odds were about 40 percent lower for each log unit change. Immigrants' nativity context had little effect on the relationships of immigrants' characteristics to migration but did render all the industry measures insignificant. Labor market wages remained the most significant deterrent of migration, particularly to new destinations but that relationship was attenuated.

After controlling for nativity, immigrants no longer had significantly increased risks of migration from new to other new destinations but they were still 35 percent more likely to migrate to traditional destinations. This divergent outcome appears due to the consistency or inconsistency of the nativity context measures and immigrants' origins. For instance, the relative risk ratios for the 23 dummy variables that measure the effects of immigrant's national origin on migration to new destinations (not shown in Table 2) are generally negative and significant, which is the same direction of the relationships for the two nativity context measures. On the other hand, the origin dummies have positive and significant effects on migration to traditional destinations, which are in the opposite direction as the nativity context measures. Although it is likely that the inconsistent directions of the origin dummies and nativity context measures account for the continued significant and positive effect of new destination residence on migration to traditional destinations, this is only an inference given that coefficients in 
multinomial logit models are difficult to interpret because they take into account the referent equation that is not shown as well as the variables in each explicit equation (Treiman, 2009).

\subsection{Changes in Probabilities of Out-Migration}

Because there is considerable origin group heterogeneity in new destination settlement and out-migration patterns, it is important to determine whether the individual and context measures do a better job of accounting for migration patterns of some groups than they do for others. That determination can be made by comparing how the unadjusted out-migration probabilities change at the group level after adjusting for the covariates in the full model (Model 3, Table 2). Before turning to that task, we first review how the unadjusted migration probabilities differ across groups. In Table 3 the unadjusted or zero-order probabilities that immigrants migrated to new or traditional destinations are shown for each origin group based on whether they lived in new destinations (columns a and c) or traditional ones (columns e and g). The origin groups are ranked by their unadjusted probabilities of out-migration from new destinations to other new destinations (column a). That ranking ranges from lows of .079 and .084 for Haitians and Salvadorans, respectively, to highs of .177 and .176 for Indians and Chinese, respectively. Of interest is the finding that Mexicans, the largest and one of the most dispersed groups, had one of the lowest probabilities of migration from new to another new destination (.087). Given the relatively high percentages of Mexicans living in new destinations (Figure 1 and Table 1), this finding underscores the importance of group size. While Mexicans accounted for 40 percent of the sample, even though they are less likely to migrate internally than immigrants from other origins, relatively large numbers of them live in different labor markets throughout the country. 
Origin groups' unadjusted out-migration percentages from new to traditional destinations also vary sharply (Column c). Mexicans and Canadians (.037 and .042) were least likely to make this move while Dominicans and Chinese were most likely (.144) to do so. Ten origins had unadjusted probabilities of migration to new destinations that were at least .05 points higher than their probabilities of migration to traditional destinations (compare columns a and c). This heterogeneous set includes Indians, Filipinos, Canadians, Pakistanis and Koreans, which have high-skill human capital profiles; groups, such as Laotians and Vietnamese, which have a history of immigration and settlement linked to refugee programs; and groups, such as Mexicans, Guatemalans and Hondurans, which have low-skill human capital profiles. In contrast, two groups, Dominicans and Haitians, were more likely to migrate from new to traditional destinations and others, including Cubans, Guyanese and Ecuadorians, were about as likely to migrate to new as to traditional destinations. Included in the equal probability category are the Taiwanese who have exactly the same probabilities of migration to both destinations (.138). The remaining eight origins had modestly higher probabilities of migration to new, rather than traditional destinations. For 18 of the 24 groups, the dominant migration pattern was to new destinations.

These findings indicate that immigrants already living in new destination areas were an important source of new destination immigrants. However, it is also the case that since most immigrants lived in traditional areas in 1995 they accounted for an equivalent share of inmigrants to new destinations even though their out-migration rates were lower. Similarly to those in new destinations, the total row in Table 3 indicates that most immigrants in traditional areas moved to new rather than traditional destinations (compare columns e and g) but that pattern did not hold for all groups. The unadjusted probabilities in Column "e" show that Laotians, 
Canadians, Pakistanis and Indians had the highest probabilities of migration from traditional to new destinations (.092 to .079 range) while Guyanese, Dominicans, Jamaicans, Cubans, Ecuadorans and Haitians were least likely to make that move (.020 to .027 range). These statistics indicate that the dispersal process is proceeding slowly or not at all for groups such as Dominicans and Guyanese in that they have low rates of out-migration from the traditional areas where they are highly concentrated and if they do move internally, they are more likely to move to other traditional destinations rather than to new destinations. Nevertheless, the dominant tendency for immigrants in both traditional and new destinations was gradual dispersion to new destinations.

By comparing the adjusted probabilities based on separate group models to the unadjusted ones for each group, we can evaluate the explanatory power of the model in accounting for each group’s migration patterns. Figure 3 ranks groups by the relative percentage change in the unadjusted probabilities of out-migration from new to either new or traditional destinations after adjustment for the effects of model covariates. The adjusted probabilities for out-migration to new destinations are shown by the black bars in Figure 3 ([(column b - column a)/column a] * 100) while those for out-migration to traditional destinations are shown by the grey bars ([(column d - column c)/column c] * 100). The black bars indicate that model covariates accounted for a substantial share of each group's out-migration likelihood from new to other new destinations although the magnitude of the adjustments varied across groups. While Canadians, Laotians, Hondurans, Guatemalans, Mexicans and Vietnamese had relatively small reductions in their out-migration probabilities, 15 groups had reductions of at least 40 percent and Dominicans, Guyanese, Ecuadoreans, and Cubans had reductions of over 60 percent. Despite this 
substantial variation in the magnitude of model effects, all the groups still had higher probabilities of out-migration from new to other new destinations.

The grey bars in Figure 3 indicate that the model also accounted for a substantial share of each group's out-migration to new versus traditional destinations. The unadjusted probabilities were reduced for 21 groups but increased for Canadians, Brazilians and Laotians. For about half of the groups, the magnitude of the adjustment was smaller than it was for migration within the new destination category but it was about the same or larger for others, including Hondurans, Salvadorans, Pakistanis, Haitians, Ecuadorans, and Guyanese. Only eight groups (Ecuadorians, Guyanese, Cubans, Dominicans, Chinese, Haitians, Iranians, and Nicaraguans) had adjustments greater than 40 percent. The adjustments in Figure 3 indicate that immigrants who lived in new destinations had higher probabilities of out-migration to both other new and traditional destinations than suggested by their human capital, demographic, and assimilation profiles in combination with their labor market economic and nativity contexts.

Figure 4 summarizes comparable adjustments for out-migration from traditional areas to new or traditional destinations. The black bars show the adjustment for migrations to new destinations ([(column $\mathrm{f}$ - column e)/column e] * 100) while those for out-migration to traditional destinations are shown by the grey bars ([(column $\mathrm{h}$ - column g)/column g] * 100). In contrast to the adjustments shown in Figure 3, the adjusted probabilities from traditional to new destinations are larger than the unadjusted ones for all 24 groups. This finding means that immigrants should be more likely to migrate from traditional to new destinations given their characteristics and contexts. However, the increased adjustments were quite small for several of the lower human capital groups - Haitians, Salvadorans, Hondurans, Guatemalans, and Dominicans had adjustments less than 20 percent. In contrast most of the high human capital groups, including 
Chinese, Taiwanese, Iranians, Koreans, Indians, Filipinos, Brazilians, and Pakistanis) had adjustments greater than 40 percent. These findings reflect the strong retention power of immigrant's traditional places. Figure 4 also indicates that immigrants living in traditional places were less likely to migrate to other traditional destinations than would be expected given their characteristics but this adjustment effect is smaller for most groups than that for migration to new destinations. For 13 groups the adjustment is less than 20 percent of the unadjusted probability and it is greater than 40 percent for only four groups (China, Taiwan, Iran and Pakistan).

\subsection{Sensitivity Model Assessments}

In order to explore more fully whether the findings hold up under different model specifications, additional models were estimated. One concern was to explore the effect that Mexicans had on the combined model given that they constitute 40 percent of the sample, have relatively low levels of human capital, and are more dispersed than other groups. To make that determination we re-estimated the full model (Model 3, Table 2) substituting an interaction term between national origin and each origin's labor market group size in order to control for the disproportionate weighting that Mexicans have on the coefficient for the continuous nativity concentration measure. That model generated coefficients for the individual covariates that were comparable to those in Model 3 but there were a few changes in the coefficients for context measures. For instance, out-migration from the West to traditional destinations was no longer significant in that model and three of the industrial sector measures became significant. We also estimated a separate multinomial model for Mexicans that used a refined 5-category destination measure. Although Model 3, Table 2, showed that the odds of leaving the West for another traditional destination were modest (odds ratio of 1.252), in the model estimated for Mexicans 
only, those in the West were twice as likely to migrate to another traditional destination (1.982, model not shown but available upon request). Compared to estimates for the full sample (Model 3, Table 2), Mexicans who were male, spoke English fluently or very well, or worked in blue collar jobs had significantly higher odds of migration to new destinations while those who had been in the country longer or lived in labor markets with higher wages had significantly lower ones.

We then estimated a model that included all groups except Mexicans and found little change in the individual covariates but increased significance for several of the industrial sector covariates compared to those in Model 3, Table 2. The only individual covariate change of note was a switch from non-significant to significant for English language fluency - that ability increased odds of migration to traditional as well as to new destinations relative to non-fluent immigrants. Labor market average wages also had a stronger deterrent impact on out-migration to both destinations in the non-Mexican model while employment percentages in the professional sector significantly increased those odds. In addition, other immigrants were significantly less likely to go to new destinations if they lived in labor markets with high job shares in the residential growth sector. While the pseudo R-squared jumped from .08 in Model 3, Table 2, to .108 in the non-Mexican model, the pseudo R-squared terms for logistic regression models are not directly comparable to the R-squared term in OLS models and thus should not be used as indicators of the proportion of the variance explained by the model. Rather, the best use of these terms is to compare the fit of multiple models for the same predictor based on changes in estimator variables. ${ }^{\text {vi }}$

We used the log likelihood ratio test to evaluate the relative importance of model covariates and found that the individual measures, which control for immigrants' demographic, 
human capital and acculturation characteristics accounted for the largest change in model log likelihoods, followed by the nativity indicators (national origin; context nativity concentration; context change in foreign-born size), geographic indicators (1995 residence in new destinations; region of the country), and economic context (average wages; industrial structure). All four variable subsets were significant predictors of immigrant's internal migrations. We expected to find that immigrants' individual characteristics would be the most important determinants of migration given that previous research shows that people's human capital and demographic characteristics are key determinants of internal migration. At the same time, immigrants’ individual characteristics did not account for why immigrants were more likely to migrate from new destinations to traditional or other new destinations because the effects of those measures on migration are comparable for immigrants regardless of their origins (see Model 1, Table 2). Instead, the observed migration differentials stemmed largely from the economic context of the labor market where immigrants lived, particularly on how its wages compared to those of other areas, and its nativity context. Other log likelihood ratio tests on the nativity measures indicated that nativity concentration and foreign-born change in immigrant's residence context were more important predictors of migration than national origin alone.

\section{Conclusions and Discussion}

This analysis has focused on explaining why immigrants who lived in new destinations in 1995 were twice as likely to migrate internally as immigrants living in traditional destinations and whether immigrants were more likely to migrate to other new or traditional destinations. Both individual and context characteristics of immigrants in their 1995 places of residence were examined and found to be important in shaping migration outcomes. The findings for 
immigrants' individual characteristics are consistent with previous studies and show that immigrants are more likely to migrate internally if they are male, speak English well or very well, and are highly educated, but less likely to migrate if they are citizens, arrive in the USA at an older age, or have longer U.S. residence duration. We also examined additional individual characteristics and found that immigrants working in health occupations are highly mobile and especially likely to migrate to new destinations. Other professionals are also mobile but have mixed destination preferences - STEM workers, for instance, prefer traditional destinations while other professionals are equally attracted to new and traditional destinations. Additional findings for immigrants' individual characteristics indicated that never married immigrants were less likely to migrate to new destinations as were immigrants who lived in the Northeast. Immigrants in the South had the highest rates of internal migration to new destinations. Most individual characteristics had comparable effects on migration to both types of destinations but highly educated immigrants preferred traditional destinations where opportunities for those with high skills are concentrated.

Although immigrants' individual characteristics were the most important overall determinants of migration, they did not account for immigrants' migration differentials because they have comparable effects across groups. Instead, migration differentials were accounted for largely by the economic context of the labor markets where immigrants lived, particularly by their wage levels and nativity contexts. Immigrants living in labor markets with higher wages were less likely to migrate internally, particularly to new destinations. We also looked at how employment shares in selected industrial sectors affected out-migration and found that most of those indicators did not have significant effects on out-migration but were of some importance in models estimated for non-Mexicans. In general, non-Mexican immigrants were significantly 
more likely to migrate if they lived in labor markets with higher wages and employment shares in agriculture or professions and less likely to leave ones with higher employment shares in the residential growth sector. We argued that these findings probably stem from the higher mobility of professional workers and onward migration flows out of areas with high rates of in-migration.

Controlling for labor market context significantly reduced out-migration from new to other new and traditional destinations but did not fully account for them. Immigrant's nativity context was a critical additional factor. Whether immigrants migrate internally is strongly determined by their nativity context and origins. Immigrants who lived in labor markets of high nativity concentration or that had higher percentage change in total foreign-born population between 1990 and 2000 were significantly less likely to migrate internally. Indeed controlling for nativity context and origins accounted for out-migration from new to other new destinations. That finding reflects both immigrants' strong sensitivity to the presence of co-ethnics and the fact that all immigrant groups were less likely than Canadians (the reference group) to migrate to new destinations net of other individual and context characteristics. While additional analysis is needed to specify causal dynamics more fully, the analysis shows that immigrants who resided in labor markets with relatively large co-ethnic populations in 1995 were less likely to migrate and that this effect persists even for new destinations with co-ethnic numbers that would be considered small compared to those in traditional labor markets. Some new destinations had almost no co-ethnics while others had what might be termed modest numbers. Further research is needed to determine whether there is a nativity concentration threshold point and how it differs for immigrants from different origins.

The analysis confirmed that there is considerable diversity among Asian, Caribbean and Latin American immigrants in their internal migration propensities. Internal migration rates vary 
greatly by national origin as do dispersion tendencies and compositions of places that make up each group's set of new destinations. Group heterogeneity creates a major challenge for the study of foreign-born settlement shifts. The analysis confirms that immigrants are dispersing to places where relatively few of their co-ethnics have previously settled and also indicates that most of them migrating internally during the 1990s moved from new to traditional destinations. This onward migration pattern suggests that immigrants find new destinations attractive but are still exploring non-traditional areas. While the evidence of dispersion applies to all national origin groups, there exists considerable heterogeneity across groups in both the pace and pattern of this dispersion. Immigrants from many origins have relatively large shares already settled in new destinations and high probabilities of migration from new to both new and traditional destinations. Most of these immigrants come from Asian countries with relatively high-skill profiles such as India, China, Pakistan, Korea and Taiwan. The pattern for these high skilled immigrants appears to be strongly shaped by the search for employment commensurate with their skills. In addition, the determinants of migration flows for the high-skill groups are consistent with classic assimilation theory. The dispersion patterns for Colombians and Brazilians also fit this pattern.

Other Americas groups, in contrast, especially those from Central America that have lowskill profiles, tend to have relatively low rates of settlement in new destinations but if they do live in those areas, they have above average probabilities of migration to other new destinations and low ones to traditional destinations. This pattern suggests that Central Americans are starting to disperse in greater numbers but are doing so in response to niche economic opportunities that have opened up in new destinations in agriculture and blue collar occupations. This group includes immigrants from Guatemala, Honduras, El Salvador and Nicaragua. While there appear 
to be some affinities between these groups and Mexicans in their dispersion and skill profiles, the fact that Mexicans are a very large immigrant group and the numbers from the Central American countries are considerably smaller creates important differences. The main one, of course, is that Mexicans have one of the higher dispersion tendencies but lower rates of internal migration. Mexicans also are the least likely of all the groups to migrate from new to traditional destinations. Given that the new destination classification used in our analysis is less adequate for identifying those places for Mexicans than it is for other groups, further study is needed that looks at Mexicans alone using more refined origin and destination categories. In general the covariates in our model did a poor job of accounting for the internal migration patterns of Mexicans and Central Americans, largely because assimilation indicators have weaker or modest effects on their migration propensities. The main correlates of migration for immigrants from those origins were whether they were men, college educated, and worked in agriculture or blue collar occupations.

A third pattern characterizes the Caribbean groups. In general, immigrants from that area have very low percentages living in new destinations and very low rates of out-migration from traditional areas to new destinations. They also have lower out-migration from new destinations than the high skilled Asians or some of the low skilled Central Americans. For Caribbean immigrant groups, the main destinations of internal migrants were traditional labor markets. This pattern holds for immigrants from different cultural backgrounds - Spanish heritage for Cubans and Dominicans, French heritage for Haitians, and British heritage for Guyanese and Jamaicans. The main commonality between them is the fact that they have major settlement concentrations along the East coast of the USA, particularly the greater New York/New Jersey metropolitan area or the Miami/Fort Lauderdale corridor. To the extent that dispersion has occurred for these 
Caribbean immigrants, it has largely been toward other mid-sized metropolitan areas within close proximity to their concentrated Gateway settlements. While the explanatory model was a better fit for most of these groups than it was for Central Americans and Mexicans, the strongest predictors were the regional indicators - Caribbean immigrants living in the West, South and Midwest had a greater tendency to migrate than their Northeastern counterparts. Although the models did not identify immigrants' specific destination choices, one could speculate that much of this movement involved return migration to the east coast gateway areas that Caribbean immigrants favor or to new destinations near those areas. This suggests that for some groups the process of dispersion to places with relatively few co-ethnics creates significant discontinuities.

The analysis provides insights into whether contemporary immigrants will experience integration and assimilation patterns comparable to those of European immigrants in the past century. On the one hand, it reveals a great deal of churning in new destinations and suggests that at least some immigrants who venture out to new destinations are looking for short-term economic opportunities rather than life style changes typically associated with residence in small metropolitan and non-metropolitan areas. While our analysis provides grounds for optimism with respect to the assimilation trajectories of the new immigrants, it also suggests that there is not a single pathway into American society and economy. High-skilled immigrants from Asian countries and some Latin American ones (Colombia, Brazil) are dispersing to new destinations and the determinants of their flows appear consistent with classic assimilation theory. At the same time, immigrant groups that have lower human capital, especially those from Mexico and Central America, are also dispersing to new destinations and appear to be doing so in spite of the fact that they lack the language and human capital skills associated with assimilation. 
Whether immigrants decide to stay in those places, however, appears to be highly dependent on nativity concentrations and economic conditions, particularly wages, in the new destinations where they locate. Our analysis indicates that immigrants from most national origins are open to living in places where they have relatively few compatriots, at least over the short term, and is not inconsistent with the development of long-term settlements in many of these places in the years ahead. 
Figure 1: Percentage of Immigrant Group Living in New Destinations, 2000

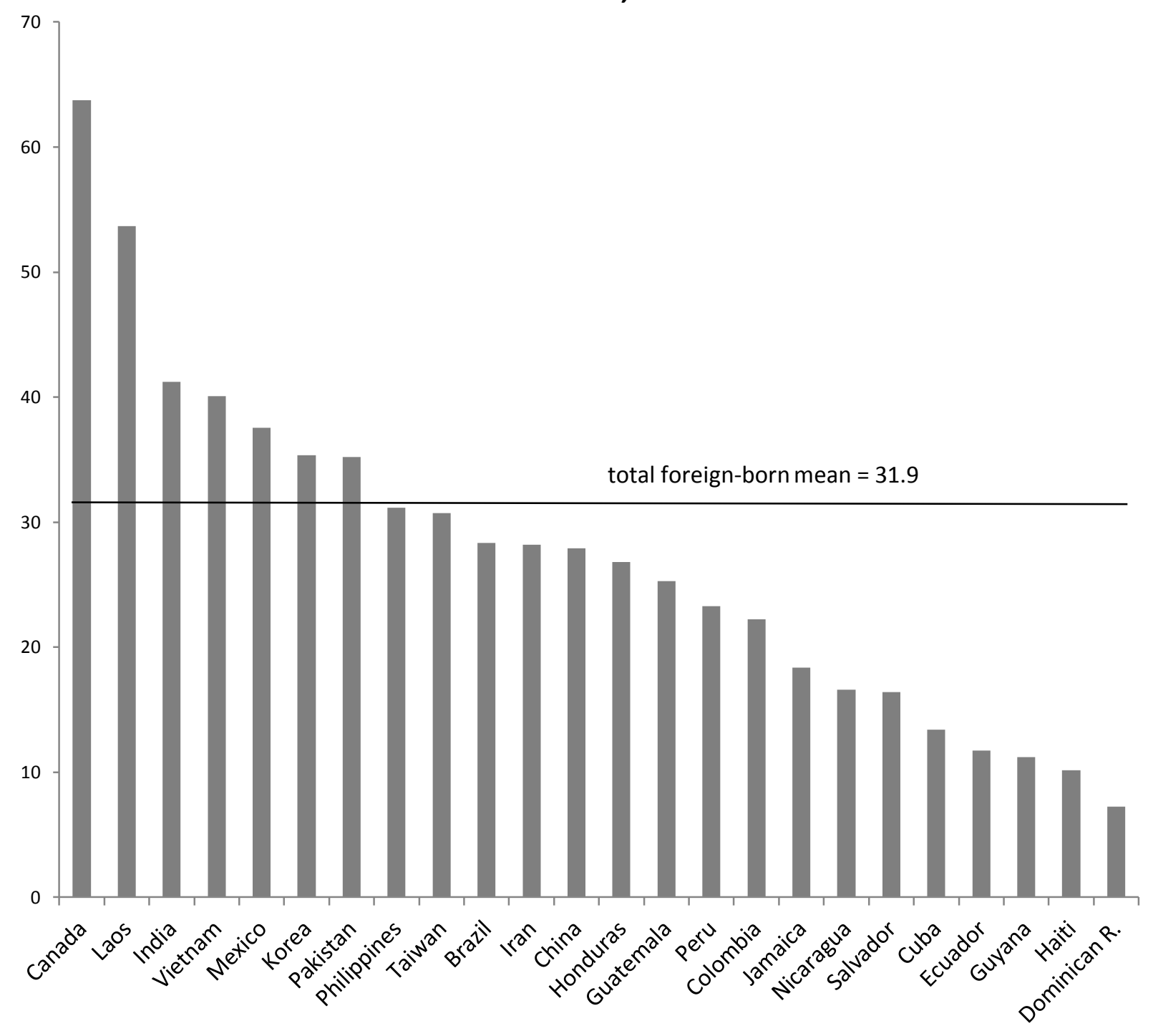

Source: U.S. Decennial Census, 16\% long-form sample accessed at New York Census Research Data Center, CISER, Cornell University 
Figure 2: Immigrants' Migration Probabilities from New (NDs) and

Traditional Destinations (TRs) to NDs versus TRs, 1995 to 2000



Source: U.S. Decennial Census, 16\% long-form sample accessed at New York Census Research Data Center, CISER, Cornell University 


\section{Figure 3: National Origin Groups' Percent Change in Probability of Migrating from New Destinations in 1995 to New or Traditional Destinations in 2000 ((adjusted-unadjusted)/unadjusted)}

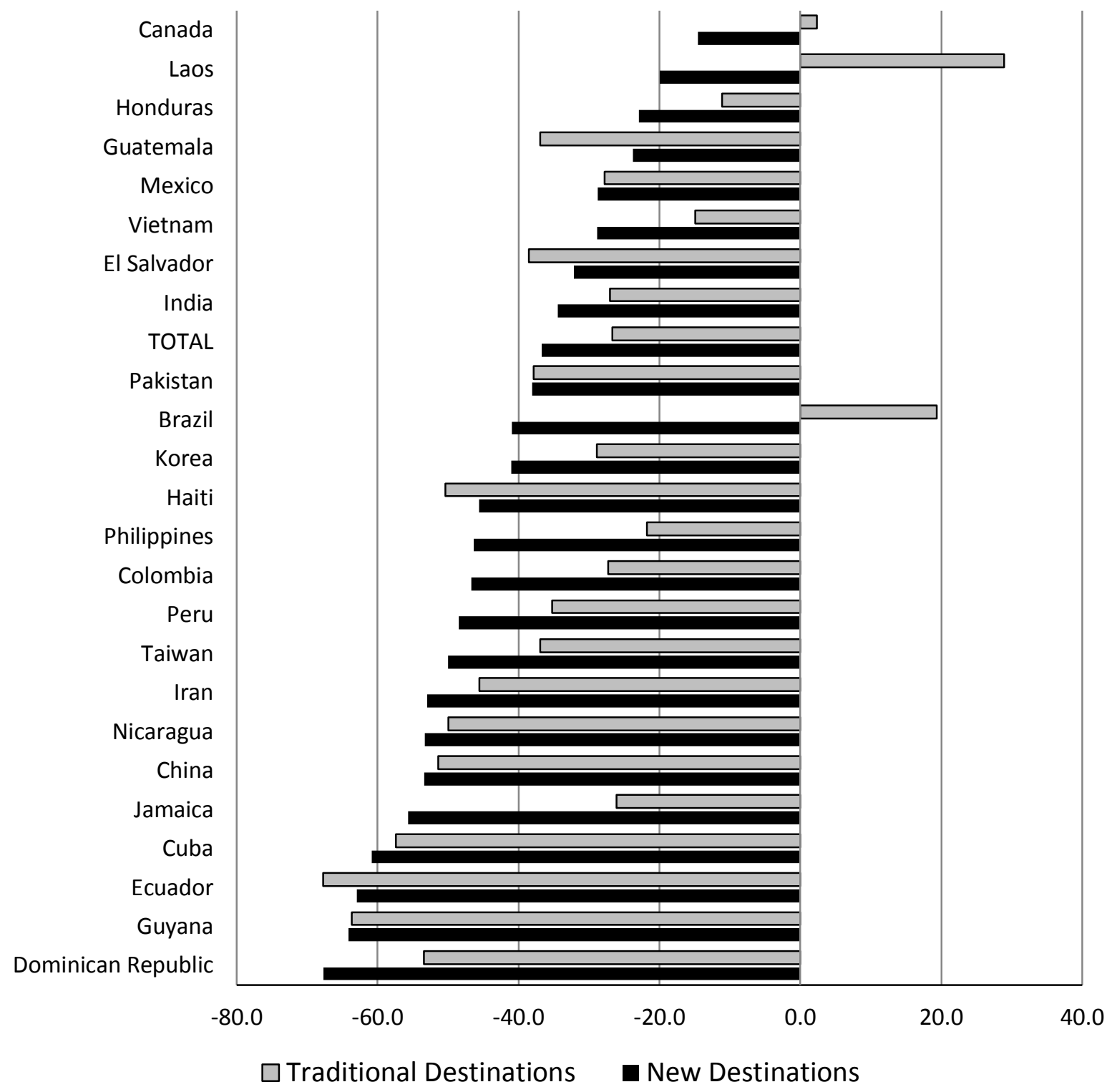

Source: U.S. Decennial Census, 16\% long-form sample accessed at New York Census Research Data Center, CISER, Cornell University

Note: The black bars show the percentage change in the unadjusted and adjusted probabilities of migration from new to other new destinations, and the grey bars show the percentage change in the unadjusted and adjusted probabilities of migration from new to traditional destinations (Table 3 ). 
Figure 4: National Origin Groups' Percent Change in Probability of Migrating from Traditional Destinations in 1995 to New or Traditional

Destinations in 2000 ((adjusted-unadjusted)/unadjusted)

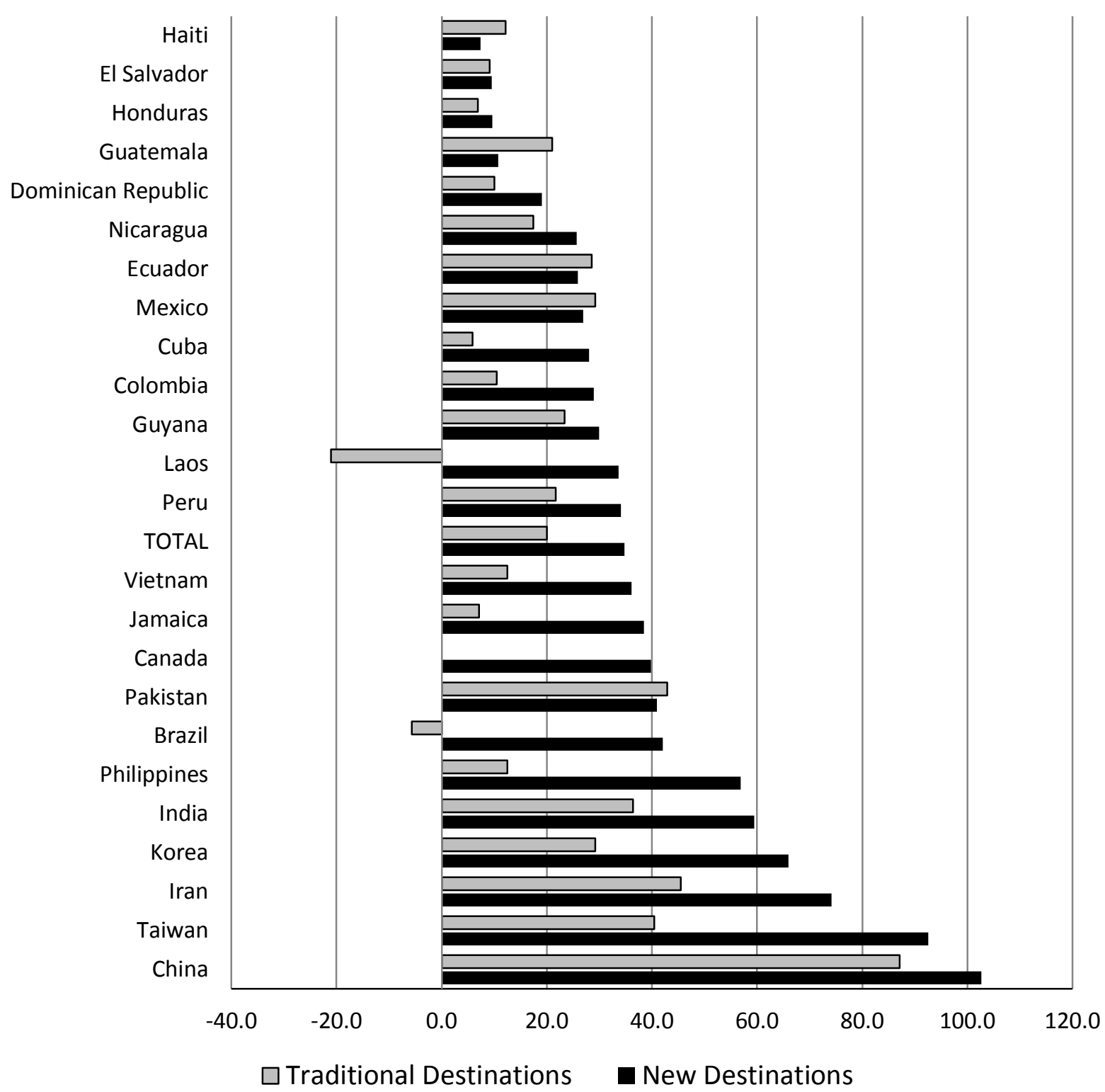

Source: U.S. Decennial Census, $16 \%$ long-form sample accessed at New York Census Research Data Center, CISER, Cornell University

Note: The black bars show the percentage change in the unadjusted and adjusted probabilities of migration from traditional to new destinations, and the grey bars show the percentage change in the unadjusted and adjusted probabilities of migration from traditional to other traditional destinations (Table3). 
Table 1: Immigrant Percentages in New Destinations and Out-Migration Percentages from New and Traditional Destinations, 1995 to 2000, by National Origin

\begin{tabular}{|c|c|c|c|c|c|}
\hline National Origin & $\begin{array}{l}\text { \% living in } \\
\text { New } \\
\text { Destinations }\end{array}$ & $\begin{array}{c}\% \\
\text { migrating } \\
\text { internally }\end{array}$ & $\begin{array}{c}\% \\
\text { migrating } \\
\text { from New } \\
\text { Destination }\end{array}$ & $\begin{array}{c}\% \\
\text { migrating } \\
\text { from } \\
\text { Traditional } \\
\text { Destination }\end{array}$ & $\begin{array}{c}\text { Population } \\
\text { size } \\
\text { (weighted), } \\
2000 \\
\end{array}$ \\
\hline 24 Group Sample & 34.3 & 10.4 & 16.9 & 7.6 & $22,091,032$ \\
\hline Mexico & 41.4 & 9.2 & 12.3 & 7.6 & $9,105,647$ \\
\hline Vietnam & 40.6 & 10.7 & 15.1 & 7.8 & 980,736 \\
\hline El Salvador & 17.6 & 7.6 & 15.4 & 6.4 & 812,336 \\
\hline Laos & 51.9 & 15.2 & 15.5 & 14.9 & 202,759 \\
\hline Nicaragua & 16.8 & 7.3 & 16.2 & 5.8 & 218,694 \\
\hline Guatemala & 29.6 & 9.4 & 16.3 & 7.5 & 477,207 \\
\hline Philippines & 31.1 & 10.2 & 16.5 & 7.6 & $1,353,169$ \\
\hline Peru & 24.6 & 8.7 & 17.2 & 6.4 & 275,973 \\
\hline Honduras & 30.0 & 11.0 & 17.6 & 9.1 & 280,138 \\
\hline Ecuador & 12.3 & 6.1 & 18.0 & 4.8 & 296,844 \\
\hline Canada & 63.4 & 16.1 & 18.6 & 11.7 & 801,405 \\
\hline Jamaica & 18.1 & 8.9 & 18.9 & 6.8 & 542,826 \\
\hline Guyana & 10.8 & 6.5 & 19.1 & 5.0 & 208,807 \\
\hline Iran & 27.9 & 10.0 & 19.1 & 6.3 & 281,500 \\
\hline Haiti & 10.4 & 7.9 & 20.0 & 6.8 & 414,628 \\
\hline Cuba & 11.9 & 7.6 & 20.1 & 5.8 & 858,149 \\
\hline Colombia & 24.4 & 10.8 & 20.3 & 8.3 & 502,880 \\
\hline Brazil & 31.1 & 12.6 & 21.5 & 9.2 & 210,254 \\
\hline Dominican Republic & 7.2 & 7.2 & 24.3 & 6.1 & 678,680 \\
\hline Pakistan & 34.7 & 16.4 & 25.8 & 11.9 & 221,870 \\
\hline Korea & 38.0 & 14.7 & 27.6 & 9.1 & 848,885 \\
\hline Taiwan & 31.2 & 14.8 & 27.6 & 8.7 & 319,034 \\
\hline India & 43.1 & 19.1 & 28.9 & 12.3 & $1,012,855$ \\
\hline China & 29.8 & 14.3 & 32.0 & 6.8 & $1,185,756$ \\
\hline
\end{tabular}

Source: U.S. Decennial Census, 16\% long-form sample accessed at New York Census Research Data Center, CISER, Cornell University 
Table 2. Multinomial Regression of Immigrants' Labor Market Out-migration to New versus Traditional Destinations on Individual and Contextual Characteristics (relative risk ratios)a

\begin{tabular}{|c|c|c|c|c|c|c|}
\hline & \multicolumn{2}{|c|}{ Model 1} & \multicolumn{2}{|c|}{$\begin{array}{c}\text { Model 2: } \\
+ \text { Economic Context } \\
\end{array}$} & \multicolumn{2}{|c|}{$\begin{array}{l}\text { Model 3: + Nativity } \\
\text { Context \& Origin }\end{array}$} \\
\hline & Traditional & $\begin{array}{c}\mathrm{New} \\
\text { Destination }\end{array}$ & Traditional & $\begin{array}{c}\mathrm{New} \\
\text { Destination }\end{array}$ & Traditional & $\begin{array}{c}\text { New } \\
\text { Destination }\end{array}$ \\
\hline \multicolumn{7}{|l|}{ Geographic Residence (1995) } \\
\hline New Destination (=1) & $2.234^{\star \star \star}$ & $2.296^{\star \star \star}$ & $1.646^{\star \star *}$ & $1.635^{\star \star \star}$ & $1.350^{\star \star \star}$ & 0.977 \\
\hline West $(=1)$ & 0.907 & $1.230^{* *}$ & $0.825^{*}$ & 1.158 & $1.252^{\star *}$ & $1.338^{\star \star}$ \\
\hline South $(=1)$ & $0.768^{\star \star}$ & $1.353^{\star \star}$ & $0.615^{\star \star \star}$ & 1.140 & $0.867^{\star}$ & $1.417^{\star \star \star}$ \\
\hline Midwest (=1) & 0.900 & $1.578^{\star \star \star}$ & $0.819^{\star *}$ & $1.246^{\star \star}$ & 0.984 & $1.206^{*}$ \\
\hline \multicolumn{7}{|l|}{ Individual Characteristics } \\
\hline College grad or more $(=1)$ & $2.428^{\star \star \star}$ & $1.725^{\star \star \star}$ & $2.523^{\star \star *}$ & $1.801^{\star \star \star}$ & $1.961^{\star \star \star}$ & $1.483^{\star \star \star}$ \\
\hline High School grad or some College $(=1)$ & $1.244^{\star \star \star}$ & $1.125^{\star \star \star}$ & $1.267^{* \star *}$ & $1.156^{\star \star \star}$ & $1.091^{\star * *}$ & $1.071^{* *}$ \\
\hline Speaks English only/very well (=1) & $1.130^{\star *}$ & $1.215^{\star \star *}$ & $1.126^{\star * *}$ & $1.215^{\star \star \star}$ & 1.038 & $1.138^{\star \star \star}$ \\
\hline Speaks English well (=1) & 0.995 & 1.013 & 0.998 & 1.018 & $0.933^{* *}$ & 0.975 \\
\hline Citizenship (=1) & $0.748^{\star \star \star}$ & $0.783^{\star * *}$ & $0.755^{\star \star \star}$ & $0.792^{\star \star \star}$ & $0.692^{\star * *}$ & $0.780^{\star \star \star}$ \\
\hline Age at Immigration (sq. root) & $0.742^{\star \star \star}$ & $0.739 * \star \star$ & $0.744^{\star * \star}$ & $0.743^{\star \star \star}$ & $0.707^{\star \star \star}$ & $0.727^{\star \star \star}$ \\
\hline Years in U.S. (sq. root) & 0.972 & $0.819^{\star \star \star}$ & 0.987 & $0.835^{\star \star \star}$ & 0.990 & $0.858^{\star \star \star}$ \\
\hline Years in U.S. squared & $0.955^{\star \star \star}$ & $0.973^{\star \star \star}$ & $0.952^{\star \star \star}$ &  & $0.949 * \star \star$ & $0.965^{\star \star \star}$ \\
\hline Male (=1) & $1.078^{\star \star \star}$ & $1.151^{\star \star \star}$ & $1.087^{\star \star \star}$ & $1.158^{\star \star \star}$ & $1.111^{\star \star \star}$ & $1.163^{\star \star \star}$ \\
\hline Never married $(=1)$ & 1.080 & $0.884^{\star \star *}$ & $1.097^{\star}$ & $0.902^{\star \star}$ & 1.071 & $0.908^{\star *}$ \\
\hline Occupation: Health $(=1)$ & $1.094^{\star \star}$ & $1.568^{\star \star \star}$ & $1.093^{\star \star}$ & $1.561^{\star \star \star}$ & $1.122^{\star \star \star}$ & $1.513^{\star \star \star}$ \\
\hline Occupation: STEM (=1) & $1.687^{\star \star \star}$ & $1.480^{\star \star \star}$ & $1.699 * \star \star$ & $1.471^{\star \star \star}$ & $1.564^{\star \star \star}$ & $1.385^{\star \star \star}$ \\
\hline Occupation: Other Professional (=1) & $1.117^{\star \star \star}$ & $1.136^{\star \star \star}$ & $1.099 * \star \star$ & $1.113^{\star \star \star}$ & $1.075^{\star}$ & $1.110^{\star \star \star}$ \\
\hline Occupation: Agriculture (=1) & $0.670^{*}$ & 1.278 & $0.551^{\star *}$ & 1.083 & $0.577^{*}$ & 1.136 \\
\hline Occupation: Blue Collar (=1) & $0.877^{\star \star}$ & $1.084^{*}$ & $0.878^{\star *}$ & 1.062 & $0.934^{*}$ & $1.104^{\star *}$ \\
\hline \multicolumn{7}{|l|}{ Labor Market Context } \\
\hline Average wage for full-time workers, 1990 (log) & & & $0.367^{\star \star \star}$ & $0.230^{\star \star \star}$ & $0.549^{*}$ & $0.450^{\star \star \star}$ \\
\hline$\%$ of employed in professional sector, 1990 & & & $1.426^{\star \star \star}$ & $1.369^{\star *}$ & 1.174 & 1.119 \\
\hline$\%$ of employed in residential growth sector, 1990 & & & 1.706 & 0.968 & 1.079 & 0.746 \\
\hline$\%$ of employed in recreational and personal services, 1990 & & & 1.046 & 1.066 & 1.079 & 1.206 \\
\hline$\%$ of employed in manufacturing, 1990 & & & 0.980 & $1.180^{\star *}$ & 0.964 & 1.098 \\
\hline$\%$ of employed in agricultural sector, 1990 & & & $1.240^{*}$ & $1.207^{\star}$ & 1.163 & 0.993 \\
\hline \multicolumn{7}{|l|}{ Nativity Context and National Origin ${ }^{a}$} \\
\hline Group Size (log) & & & & & $0.853^{\star \star \star}$ & $0.798^{\star \star \star}$ \\
\hline Foreign Born \% change, 1990-2000 (log) & & & & & $0.569 * \star *$ & $0.593^{\star \star \star}$ \\
\hline Log likelihood & \multicolumn{2}{|c|}{-4705589} & \multicolumn{2}{|c|}{-4675459} & \multicolumn{2}{|c|}{-4608974} \\
\hline Pseudo R2 & \multicolumn{2}{|c|}{0.0607} & \multicolumn{2}{|c|}{0.0667} & \multicolumn{2}{|c|}{0.0800} \\
\hline
\end{tabular}

Source: U.S. Decennial Census, 16\% long-form sample accessed at New York Census Research Data Center, CISER, Cornell University

a Models are estimated for adults, aged 25-59 (1,625,960 sample cases). Base group for the outcome is non-migrants. Model includes 23 origin dummy variables with Canadians as reference origin group. Coefficients for the origin groups are not shown but are available upon request from authors. Other referents are traditional destinations (new destinations), northeast (region), less than high school graduate (education), poor or no English (English fluency), female (sex), other or no occupation (occupation), employment in other industries or no employment (industry shares).

Note: ${ }^{\star} p<.05{ }^{* \star} p<.01{ }^{* \star *} p<.001$ 
Table 3: Unadjusted and Adjusted ${ }^{\mathrm{a}}$ Probabilities of Immigrants' Migration to Traditional and New Destination Labor Markets in 2000 by 1995 Labor Market Type and National Origin

\begin{tabular}{|c|c|c|c|c|c|c|c|c|}
\hline \multirow[b]{3}{*}{ National Origin } & \multicolumn{4}{|c|}{$\begin{array}{l}\text { \% of those who lived in } 1995 \text { new } \\
\text { destinations who migrated to: }\end{array}$} & \multicolumn{4}{|c|}{$\begin{array}{l}\text { \% of those who lived in } 1995 \text { traditional } \\
\text { destinations who migrated to: }\end{array}$} \\
\hline & \multicolumn{2}{|c|}{ New Destinations } & \multicolumn{2}{|c|}{$\begin{array}{l}\text { Traditional } \\
\text { Destinations }\end{array}$} & \multicolumn{2}{|c|}{ New Destinations } & \multicolumn{2}{|c|}{$\begin{array}{l}\text { Traditional } \\
\text { Destinations }\end{array}$} \\
\hline & $\begin{array}{l}\text { unadjusted } \\
\text { a }\end{array}$ & $\begin{array}{l}\text { adjusted } \\
\text { b }\end{array}$ & $\begin{array}{l}\text { unadjusted } \\
\text { C }\end{array}$ & $\begin{array}{c}\text { adjusted } \\
\text { d }\end{array}$ & $\begin{array}{c}\text { unadjusted } \\
\mathrm{e}\end{array}$ & $\begin{array}{c}\text { adjusted } \\
\mathbf{f}\end{array}$ & $\begin{array}{c}\text { unadjusted } \\
\mathbf{g}\end{array}$ & $\begin{array}{c}\text { adjusted } \\
\mathrm{h}\end{array}$ \\
\hline Total & .109 & .069 & .060 & .044 & .046 & .062 & .030 & .036 \\
\hline India & .177 & .116 & .111 & .081 & .079 & .126 & .044 & .060 \\
\hline China & .176 & .082 & .144 & .070 & .037 & .075 & .031 & .058 \\
\hline Pakistan & .163 & .101 & .095 & .059 & .083 & .117 & .035 & .050 \\
\hline Korea & .151 & .089 & .097 & .069 & .050 & .083 & .041 & .053 \\
\hline Canada & .144 & .123 & .042 & .043 & .088 & .123 & .029 & .029 \\
\hline Taiwan & .138 & .069 & .138 & .087 & .040 & .077 & .047 & .066 \\
\hline Brazil & .127 & .075 & .088 & .105 & .038 & .054 & .053 & .050 \\
\hline Honduras & .122 & .094 & .054 & .048 & .062 & .068 & .029 & .031 \\
\hline Guatemala & .118 & .090 & .046 & .029 & .056 & .062 & .019 & .023 \\
\hline Philippines & .110 & .059 & .055 & .043 & .044 & .069 & .032 & .036 \\
\hline Laos & .110 & .088 & .045 & .058 & .092 & .123 & .057 & .045 \\
\hline Colombia & .105 & .056 & .099 & .072 & .045 & .058 & .038 & .042 \\
\hline Vietnam & .104 & .074 & .047 & .040 & .047 & .064 & .032 & .036 \\
\hline Iran & .102 & .048 & .090 & .049 & .031 & .054 & .033 & .048 \\
\hline Peru & .101 & .052 & .071 & .046 & .041 & .055 & .023 & .028 \\
\hline Dominican Republic & .099 & .032 & .144 & .067 & .021 & .025 & .040 & .044 \\
\hline Jamaica & .097 & .043 & .092 & .068 & .026 & .036 & .042 & .045 \\
\hline Guyana & .092 & .033 & .099 & .036 & .020 & .026 & .030 & .037 \\
\hline Cuba & .092 & .036 & .108 & .046 & .025 & .032 & .034 & .036 \\
\hline Nicaragua & .090 & .042 & .072 & .036 & .035 & .044 & .023 & .027 \\
\hline Ecuador & .089 & .033 & .090 & .029 & .027 & .034 & .021 & .027 \\
\hline Mexico & .087 & .062 & .036 & .026 & .052 & .066 & .024 & .031 \\
\hline Salvador & .084 & .057 & .070 & .043 & .042 & .046 & .022 & .024 \\
\hline Haiti & .079 & .043 & .121 & .060 & .027 & .029 & .041 & .046 \\
\hline
\end{tabular}

Source: U.S. Decennial Census, 16\% long-form sample accessed at New York Census Research Data Center, CISER, Cornell University

${ }^{a}$ For the Total row adjusted probabilities were obtained using STATA's margin post-estimation command following the multinomial logit estimation summarized in Model 3, Table 3. For the origin groups, the adjusted probabilities were based on separate multinomial logit models for each group that included all covariates except origin dummy variables. 
Appendix A: Metropolitan Areas in the Top 10 Traditional Category for at least one of the largest Asian, Latin American, and Caribbean Foreign-Born Groups and Canadian Foreign Born

\begin{tabular}{|c|c|c|c|c|}
\hline$\#$ & Metropolitan Area & $\begin{array}{l}\text { Population } \\
\text { Size }\end{array}$ & $\begin{array}{l}\text { \# Groups } \\
\text { with this top } \\
10 \text { Gateway }\end{array}$ & Origin (alpha order) \\
\hline 1 & Los Angeles, CA & $16,373,645$ & 21 & all but: Dominican Rep, Jamaica, Haiti \\
\hline 2 & New York, NY & $12,068,148$ & 21 & all but: Mexico, Laos, Vietnam \\
\hline 3 & Northern $\mathrm{NJ}$ & $5,184,772$ & 20 & all but: Canada, Laos, Mexico, Vietnam \\
\hline 4 & Washington, DC/ Northern VA & $4,923,153$ & 20 & all but: Canada, Cuba, Laos, Mexico, \\
\hline 5 & San Francisco, CA & $5,101,175$ & 16 & $\begin{array}{l}\text { all but: Colombia, Cuba, Dominican Rep, } \\
\text { Ecuador, Guyana, Haiti, Honduras, Jamaica }\end{array}$ \\
\hline 6 & Chicago, IL & $8,272,768$ & 15 & $\begin{array}{l}\text { all but: Brazil, Canada, Dominican Rep, } \\
\text { Guyana, Jamaica, Laos, Nicaragua, Salvador, } \\
\text { Vietnam }\end{array}$ \\
\hline 7 & Miami, FL & $3,876,380$ & 15 & $\begin{array}{l}\text { all but: China, India, Iran, Korea, Laos, Mexico, } \\
\text { Philippines, Taiwan, Vietnam }\end{array}$ \\
\hline 8 & Boston, MA & $3,406,829$ & 14 & $\begin{array}{l}\text { all but: Cuba, Guyana, India, Iran, Korea, Laos, } \\
\text { Mexico, Nicaragua, Pakistan, Philippines }\end{array}$ \\
\hline 9 & Houston, TX & $4,669,571$ & 13 & $\begin{array}{l}\text { all but: Canada, China, Brazil, Dominican Rep, } \\
\text { Guyana, Haiti, Jamaica, Korea, Laos, } \\
\text { Philippines, Peru }\end{array}$ \\
\hline 10 & San Jose, CA & $1,938,187$ & 11 & $\begin{array}{l}\text { China, India, Iran, Korea, Mexico, Nicaragua, } \\
\text { Peru, Philippines, Salvador, Taiwan, Vietnam }\end{array}$ \\
\hline 11 & Hartford, CO & $1,183,110$ & 9 & $\begin{array}{l}\text { Brazil, Canada, Colombia, Dominican Rep, } \\
\text { Ecuador, Haiti, Jamaica, Peru, Guyana }\end{array}$ \\
\hline 12 & Seattle, WA & $3,554,760$ & 7 & $\begin{array}{l}\text { Canada, China, Korea, Laos, Philippines, } \\
\text { Taiwan, Vietnam, }\end{array}$ \\
\hline 13 & Palm Beach, FL & $1,131,184$ & 7 & $\begin{array}{l}\text { Brazil, Cuba, Colombia, Ecuador, Haiti, } \\
\text { Jamaica, Nicaragua, }\end{array}$ \\
\hline 14 & Orlando, FL & $1,644,561$ & 6 & $\begin{array}{l}\text { Brazil, Cuba, Dominican Rep, Jamaica, Laos, } \\
\text { Vietnam }\end{array}$ \\
\hline 15 & Philadelphia, PA & $6,188,463$ & 5 & $\begin{array}{l}\text { Dominican Rep, India, Jamaica, Korea, } \\
\text { Vietnam }\end{array}$ \\
\hline 16 & Dallas, TX & $3,519,176$ & 5 & Honduras, Iran, Mexico, Pakistan, Salvador \\
\hline 17 & San Diego, CA & $2,813,833$ & 5 & Iran, Laos, Mexico, Philippines, Vietnam \\
\hline 18 & Tampa/St Pete, FL & $2,395,997$ & 4 & Canada, Cuba, Dominican Rep, Guyana, \\
\hline 19 & Detroit, MI & $5,020,287$ & 3 & Canada, India, Pakistan \\
\hline 20 & Honolulu, $\mathrm{HI}$ & 876,156 & 3 & China, Korea, Philippines \\
\hline 21 & Atlanta, GA & $4,112,198$ & 2 & Guyana, Jamaica \\
\hline 22 & Phoenix, AZ & $3,251,876$ & 2 & Canada, Mexico \\
\hline 23 & Minneapolis, MN & $2,968,806$ & 2 & Laos, Guyana \\
\hline 24 & Sacramento, CA & $1,796,857$ & 2 & Laos, Vietnam \\
\hline 25 & New Orleans, LA & $1,337,726$ & 2 & Honduras, Nicaragua, \\
\hline 26 & Providence, $\mathrm{RI}$ & $1,186,613$ & 2 & Dominican Rep, Guatemala \\
\hline 27 & Fresno, CA & 922,516 & 2 & Laos, Mexico, \\
\hline 28 & Milwaukee, WI & $1,689,572$ & 1 & Laos \\
\hline 29 & Las Vegas, NV & $1,563,282$ & 1 & Cuba \\
\hline 30 & McAllen, TX & 569,463 & 1 & Mexico, \\
\hline 31 & Modesto, CA & 446,997 & 1 & Laos \\
\hline 32 & Fort Myer, FL & 440,888 & 1 & Haiti \\
\hline 33 & Chico/Butte, CA & 203,171 & 1 & Laos \\
\hline
\end{tabular}

Source: U.S. Decennial Census, 16\% long-form sample accessed at New York Census Research Data Center, CISER, Cornell University

Note: For areas 1-9, the origin column lists origin groups for which the place is not a traditional one. For areas 10-33, the origin column lists the groups for which the place is a traditional one. 
Appendix B: Definitions and Weighted Means for Immigrants' Individual Covariates, by 1995 Labor Market Type

\begin{tabular}{|c|c|c|}
\hline 0 & $\begin{array}{c}\text { New } \\
\text { Destinations, } \\
1995\end{array}$ & $\begin{array}{c}\text { Traditional } \\
\text { Destinations, } \\
1995\end{array}$ \\
\hline
\end{tabular}

\section{Outcome variable:}

Out-Migration *

$$
\begin{aligned}
& 0=\text { non-migrant } \\
& 1=\text { migrated to a gateway destination } \\
& 2=\text { migrated to new destination }
\end{aligned}
$$

$\begin{array}{lll}0.896 & 0.831 & 0.924 \\ 0.039 & 0.060 & 0.030 \\ 0.065 & 0.109 & 0.046\end{array}$

\section{Individual Variables}

1995 New Destination (=1)

West in 1995 (=1)

Northeast in 1995 (=1)

Midwest in 1995 (=1)

South in $1995(=1)$

Male (=1)

0.396

1.000

0.000

Never married $(=1)$

0.451

0.378

0.499

0.195

0.135

0.237

0.088

0.106

0.076

College or more $(=1)$

0.266

0.385

0.188

0.505

0.515

0.499

0.168

0.151

0.179

High school graduate or some college (=1)

0.204

0.214

0.197

Less than high school (=1)

0.361

0.349

0.369

Speaks English only or very well (=1)

0.435

0.437

0.434

Speaks English well (=1)

Speaks English poorly or not at all (=1)

0.423

0.446

0.408

0.248

0.237

0.256

Citizen (=1)

0.329

0.317

0.336

Age at Immigration

0.447

0.434

0.447

Years in U.S.A.

22.105

21.799

22.306

Health occupation (=1)

17.395

0.175

0.173

STEM occupation (=1)

0.038

0.043

0.035

Other Professional occupation (=1)

0.033

0.037

0.030

Agricultural occupation (=1)

0.041

0.044

0.039

Blue Collar occupation $(=1)$

0.043

0.070

0.025

0.241

0.244

0.239

Source: All statistics are from the 2000 U.S. Decennial Census. The out-migration statistics are from the $16 \%$ long-form file and all other statistics are from the 5\% PUMS. The means were calculated for foreign-born persons who were in the United States in 1995 and aged 25-59 in 2000. 


\section{References}

Bartel, A.P., Koch, M.J., 1991. Internal Migration of US Immigrants. In: Abowd, J. M., and Freeman, R. B., (Eds.), Immigration, Trade, and the Labor Market. The University of Chicago Press, Chicago, pp. 121-134.

Belanger, A., Rogers, A., 1994. The Internal Migration and Spatial Redistribution of the Foreign-born Population in the United States: 1965-70 and 1975-80. International Migration Review XXVI, 13421369.

Breton, R., 1964. Institutional Completeness of Ethnic communities and the Personal Relations of Immigrants. The American Journal of Sociology 70, 193-205.

Broadway, M.J., Ward, T., 1990. Recent Changes in the Structure and Location of the U.S. Meatpacking Industry. Geography 75, 76-79.

Brown, L.A., Lobao, L., Digiacinto, S., 1999. Economic Restructuring and Migration in an Old Industrial Region. In: Pandit, K., and Withers, S. D., (Eds.), Migration and Restructuring in the United States: A Geographic Perspective. Rosman \& Littlefield Publishers, Inc., New York, pp. 37-58.

Bump, M.N., Lowell, B.L., Pettersen, S., 2005. The Growth and Population Characteristics of Immigrants and Minorities in America's New Settlement States. In: Goździak, E. M., and Martin, S. F., (Eds.), Beyond the Gateway: Immigrants in a Changing America. Lexington Books, New York, pp. 19-53.

Camarota, S.A., Keeley, J., 2001. The New Ellis Islands: Examining Non-Traditional Areas of Immigrant Settlement in the 1990s, Backgrounder. Center for Immigration Studies, Washington, D.C., pp. 1-8. http://www.cis.org/ImmigrantSettlement1990s.

Carlson, E., 1985. The impact of international migration upon the timing of marriage and childbearing. Demography 22, 61-72. http://dx.doi.org/10.2307/2060986.

Davey, M., 2007. Immigration, and Its Politics, Shake Rural Iowa, New York Times, New York. http://www.nytimes.com/2007/12/13/us/politics/13voices.html?_r=1\&oref=slogin\&ref=todayspaper\&pag ewanted=print.

Donato, K.M., Tolbert, C.M., Nucci, A., Kawano, Y., 2007. Recent Immigrant Settlement in the Nonmetropolitan United States: Evidence from Internal Census Data. Rural Sociology 72, 537-559.

Durand, J., Massey, D.S., Capoferro, C., 2005. The New Geography of Mexican Immigration. In: Zúñíga, V., and Hernández-León, R., (Eds.), New Destinations: Mexican Immigration in the United States. Russell Sage Foundation, New York, pp. 1-20.

Ellis, M., Goodwin-White, J., 2006. 1.5 Generation Internal Migration in the US: Dispersion from States of Immigration? International Migration Review 40, 899-926.

Ellis, M., Wright, R., Parks, V., 2006. The Immigrant Household and Spatial Assimilation: Partnership, Nativity, and Neighborhood Location. Urban Geography 27, 1-19.

Fang, D., Brown, D., 1999. Geographic Mobility of the Foreign-Born Chinese in Large Metropolises, 1985-1990. International Migration Review 33, 137-155. 
Fischer, M.J., 2010. Immigrant educational outcomes in new destinations: An exploration of high school attrition. Social Science Research 39, 627-641. http://www.sciencedirect.com/science/article/B6WX84Y9S VP9-1/2/ecb03ea27498e56309a970183f34a320.

Fischer, M.J., Tienda, M., 2006. Redrawing Spatial Color Lines: Hispanic Metropolitan Dispersal, Segregation, and Economic Opportunity. In: Tienda, M., and Mitchell, F., (Eds.), Hispanics and the Future of America. National Academies Press, Washington, D.C., pp. 100-131.

Frey, W.H., 2005. Metro America in the New Century: Metropolitan and Central City Demographic Shifts Since 2000, Living Cities Census Series. The Brookings Institution, Washington, D.C., pp. 27.

Frey, W.H., Liaw, K.-L., 1999. Internal Migration of Foreign-born Latinos and Asians: Are They Assimilating Geographically? In: Pandit, K., and Withers, S. D., (Eds.), Migration and Restructuring in the United States. Rowman and Littlefield, New York, pp. 212-230.

Frey, W.H., Liaw, K.L., 2005. Migration within the United States: Role of Race-Ethnicity, BrookingsWharton Papers on Urban Affairs, pp. 207-262. http://muse.jhu.edu/journals/brookingswharton_papers_on_urban_affairs/v2005/2005.1frey.html.

Frey, W.H., Liaw, K.L., 2006. Migration within the United States: Role of Race-Ethnicity. Brookings Institution Metropolitan Policy Program, Washington, D.C., pp. 207-260.

Funkhouser, E., 2000. Changes in the Geographic Concentration and Location of Residence of Immigrants. International Migration Review 34, 489-510. http://www.jstor.org/stable/2675911

Goździak, E.M., Martin, S.F., 2005. Beyond the Gateway: Immigrants in a Changing America. Lexington Books, New York.

Greenwood, M.J., 1981. Migration and Economic Growth in the United States. Academic Press, New York.

Greenwood, M.J., 1997. Internal Migration in Developed Countries. In: Rosenzweig, M. R., and Stark, O., (Eds.), Handbook of Population and Family Economics. Elsevier Science, New York, pp. 647-720.

Gurak, D.T., Kritz, M.M., 2000. The Interstate Migration of U.S. Immigrants: Individual and Contextual Determinants. Social Forces 78, 1017-1039.

Haug, S., 2008. Migration Networks and Migration Decision-Making. Journal of Ethnic and Migration Studies 34, 585-605.

http://www.informaworld.com/smpp/content content=a791641456 db=all jumptype=rss.

Heer, D.M., 2002. When Cumulative Causation Conflicts with Relative Economic Opportunity: Recent Change in the Hispanic Population of the United States. Migraciones Internacionales 1, 32-53.

Hirschman, C., Massey, D.S., 2008. Places and Peoples: The New American Mosaic. In: Massey, D. S., (Ed.), New Faces in New Places: The Changing Geography of American Immigration. Russell Sage Foundation, New York, pp. 1-21.

Kandel, W., Cromartie, J., 2004. New Patterns of Hispanic Settlement in Rural America. U.S. Department of Agriculture, Washington, D.C.

Kandel, W., Parrado, E.A., 2004. Industrial Transformation and Hispanic Migration to the American South: The Case of the Poultry Industry. In: Arreola, D., (Ed.), Hispanic Spaces, Latino Places: A Geography of Regional and Cultural Diversity. University of Texas Press, Austin, pp. 255-276. 
Kandel, W., Parrado, E.A., 2005. Restructuring of the U.S. Meat Processing Industry and New Hispanic Migrant Destinations. Population and Development Review 31, 447-471.

Kritz, M.M., Gurak, D.T., 2004. Immigration and a Changing America. In: Farley, R., and Haaga, J., (Eds.), The American People: Census 2000. Russell Sage Foundation, Washington, DC, pp. 259-301.

Kritz, M.M., Gurak, D.T., Lee, M.A., 2011. Will They Stay? Foreign-Born Out-Migration from New U.S. Destinations. Population Research and Policy Review 30, 537-567.

http://www.springerlink.com/content/l3gk5155h5k41874/.

Kritz, M.M., Nogle, J.M., 1994. Nativity Concentration and Internal Migration Among the Foreign-Born. Demography 31, 509-524.

Landale, N.S., 1994. Migration and the Latino Family: The Union Formation Behavior of Puerto Rican Women. Demography 31, 133-157. http://www.jstor.org/stable/2061912.

Leach, M.A., Bean, F.D., 2008. The Structure and Dynamics of Mexican Migration to New Destinations in the United States. In: Massey, D. S., (Ed.), New Faces in New Places: The Changing Geography of American Immigration. Russell Sage Foundation, New York, pp. 51-74.

Lee, M., Ferraro, K.F., 2007. Neighborhood Residential Segregation and Physical Health among Hispanic Americans: good, Bad, or Benign? Journal of Health and Social Behavior 48, 131-148.

Ley, D., 2007. Countervailing Immigration and Domestic Migration in Gateway Cities: Australian and Canadian Variations on an American Theme. Economic Geography 83, 231-254.

Lichter, D.T., Johnson, K.M., 2006. Emerging Rural Settlement Patterns and the Geographic Redistribution of America's New Immigrants. Rural Sociology 71, 109-131.

Lichter, D.T., Johnson, K.M., 2009. Immigrant Gateways and Hispanic Migration to New Destinations. International Migration Review 43, 496-518.

Lieberson, S., Waters, M., 1987. The Location of Ethnic and Racial Groups in the United States. Sociological Forum 2, 780-810.

Light, I.H., 2006. Deflecting Immigration: Networks, Markets, and Regulation in Los Angeles. Russell Sage Foundation, New York.

Logan, J.R., Alba, R.D., Zhang, W., 2002. Immigrant Enclaves and Ethnic Communities in New York and Los Angeles. American Sociological Review 67, 299-322.

Massey, D.A., 1995. The New Immigration and Ethnicity the United States. Population and Development Review 21, 631-652.

Massey, D.S., 2008. New Faces in New Places: The Changing Geography of American Immigration. Russell Sage Foundation, New York.

Massey, D.S., Alarcon, R., Durand, J., Gonzales, H., 1987. Return to Aztlan: The Social Process of International Migration from Western Mexico. University of California Press, Berkeley, CA.

Massey, D.S., Capoferro, C., 2008. The Geographic Diversification of American Immigration. In: Massey, D. S., (Ed.), New Faces in New Places: The Changing Geography of American Immigration. Russell Sage, New York, pp. 25-50. 
Massey, D.S., Sánchez, M., 2009. Restrictive Immigration Policies and Latino Immigrant Identity in the United States, Human Development Research Papers. United Nations Development Programme, New York. http://hdr.undp.org/en/reports/global/hdr2009/papers/HDRP_2009_43.pdf.

Millard, A.V., Chapa, J., 2004. Apple Pie and Enchiladas: Latino Newcomers in the Rural Midwest. University of Texas Press, Austin.

Moretti, E., 2012. The New Geography of Jobs. Houghton Mifflin Harcourt, Boston.

Nogle, J.M., 1997. Internal Migration Patterns for U.S. Foreign-Born, 1985-1990. International Journal of Population Geography 3, 1-13.

Odem, M.E., Lacy, E.C., 2009. Latino Immigrants and the Transformations of the U.S. South. University of Georgia Press, Athens.

Parrado, E.A., Kandel, W., 2008. New Hispanic Migrant Destinations: A Tale of Two Industries. In: Massey, D. S., (Ed.), New Faces in New Places: The Changing Geography of American Immigration. Russell Sage Foundation, New York, pp. 99-123.

Portes, A., 1995. Economic Sociology and the Sociology of Immigration. In: Portes, A., (Ed.), The Economic Sociology of Immigration. Russell Sage Foundation, New York, pp. 1-41.

Portes, A., Rumbaut, R.G., 2001. Legacies: The Story of the Immigrant Second Generation. University of California Press, Berkeley, CA.

Portes, A., Zhou, M., 1993. The New Second Generation: Segmented Assimilation and Its Variants among Post-1965 Immigrant Youth. Annals of the American Academy of Political and Social Science 530, 74-96.

Rebhun, U., 2006. Nativity Concentration and Internal Migration among the Foreign-Born in Israel, 1990-1995. Revue européenne des migrations internationales 22, 1-22.

Singer, A., 2004. The Rise of New Immigrant Gateways, Brookings Institution Living Cities Census Series. Brookings Institution, Washington, D.C.

Smith, H.A., Furuseth, O.J., 2006. Latinos in the New South. Ashgate, London.

Smith, J.P., Edmonston, B.E., 1997. The New Americans: Economic, Demographic, and Fiscal Effects of Immigration. In: Council, N. R., (Ed. National Academy Press, Washington, D.C.

Stamps, K., Bohon, S.A., Educational Attainment in New and Established Latino Metropolitan Destinations. Population Association of America, Los Angeles, 2006.

Suro, R., Singer, A., 2002. Latino Growth in Metropolitan America: Changing Patterns, New Locations, Brookings Census 2000 Survey Series. Brookings Institution Center on Urban and Metropolitan Policy and Pew Hispanic Center, Washington, D.C.

Tienda, M., Wilson, F.D., 1992. Migration and the Earnings of Hispanic Men. American Sociological Review 57, 661-678.

Tolbert, C.M., Blanchard, T.C., Irwin, M.D., 2006. Stability and Change in Individual Determinants of Migration: Evidence from 1985-90 and 1995-2000. In: Nguyen, S. V., (Ed., Discussion Papers, Center for Economic Studies. U.S. Bureau of the Census, Washington, DC, pp. 31. http://www.ces.census.gov/index.php/ces/cespapers?limit=40\#table. 
Tolbert, C.M., Sizer, M., 1996. U.S. Commuting Zones and Labor Market Areas: A 1990 Update, ERS Staff Paper Number 9614. Economic Research Service, Rural Economy Division, U.S. Department of Agriculture, Washington, D.C.

Treiman, D., 2009. Quantitative Data Analysis: Doing Social Research to Test Ideas. Jossey-Bass (Wiley), San Francisco.

UCLA, A.T.S., 2011. What are pseudo R-squareds? In: group, S. C., (Ed., Los Angeles. http://www.ats.ucla.edu/stat/mult_pkg/faq/general/psuedo_rsquareds.htm.

Van Hook, J., Glick, J.E., 2007. Immigration and Living Arrangements: Moving Beyond Economic Need Versus Acculturation. Demography 44, 225-249.

Waters, M., Lieberson, S., 1988. From Many Strands: Ethnic and Racial Groups in Contemporary America. Russell Sage Foundation, New York.

Winders, J., 2005. Changing Politics of Race and Region: Latino Migration to the U.S. South. Progress in Human Geography 29, 683-699.

Zhou, M., 1999. Segmented Assimilation: Issues, Controversies, and Recent Research on the New Second Generation. In: Hirschman, C., Kasinitz, P., and DeWind, J., (Eds.), The Handbook of International Migration: The American Experience. Russell Sage Foundation, New York, pp. 196-211.

Zúñíga, V., Hernández-León, R., 2005. New Destinations: Mexican Immigration in the United States Russell Sage Foundation, New York. 


\section{Endnotes}

${ }^{i}$ We use the terms "immigrants" and "foreign-born" interchangeably in this paper. Although immigrants are the population of interest, decennial censuses, the main source of empirical data, have data on place of birth rather than official residency status. Many foreign born are non-resident aliens who return to their homelands after their visas expire and others are illegal migrants who also leave.

${ }^{\text {ii }}$ Foreign physicians and other health professionals who agree to work in underserved areas are granted J-1 visas which require them to work in an underserved area for 3 years. However, the health institution that sponsored a medical worker's application can request that the visa be renewed or it can sponsor them for permanent residency, in which case they could move wherever they wish.

iii American Community Survey (ACS) data have replaced the long-form decennial census but samples released to date, including the five-year public use and confidential use files, have less than half the foreign-born cases that were available in the 2000 decennial census. Based on our preliminary comparisons of the confidential files for the 2000 census and the 2005-2009 ACS, we have identified several geographic areas that had foreign born in 2000 but where no foreign born were found in the five-year files. Measuring internal migration using the single year ACS migration question also produces fewer migrants than used to be generated using the five year decennial census measure.

${ }^{\text {iv }}$ Alternative cut points of 8 and 12 were examined but did not alter findings. We also explored the use of 3 destination categories (top 5, top 10, and others) and found that migration patterns for the top 5 and top 10 categories were comparable, which justifies combining them into a single category. For groups such as Mexicans which have large population numbers in a large number of Western and Southwestern metropolitan areas, using a smaller number of traditional areas would not be prudent. Smaller immigrant groups, on the other hand, do not have enough immigrants in areas beyond the top 10 to introduce further refinement into the new destination category. We also examined patterns that based the traditional and new destination categories on the size of the total foreign-born population rather than the distributions of discrete groups and found another problem, namely that that the top ten category largely corresponded to the top ten areas for Mexicans. This is not surprisingly given that Mexicans comprised about 40 percent of the total foreign-born population in 2000. More importantly, many groups do not have large settlements in the top ten places based on the ranking for the total foreign born. Appendix $\mathrm{A}, 5^{\text {th }}$ column, shows, for instance, that Los Angeles is not an important settlement area for Dominicans, Jamaicans or Haitians, nor is New York an important place for Mexicans, Laotians, and Vietnamese although given the size of the Mexican immigrant population, there probably would be sufficient numbers of them for analytic purposes. For the analysis carried out in this paper, each origin group has to have a sufficient number of cases (about a 100) in each traditional area. That same requirement applies to the new destination category.

${ }^{\mathrm{v}}$ The highest aggregate measure correlations occur for: 2000-1990 percentage change in foreign-born population and foreign-born group size (-0.413); and 1990 average wage for full-time employed workers and foreign-born group size (0.411).

${ }^{v i}$ Multinomial logistic regression produces maximum likelihood estimates that are arrived at through an iterative process. They are not calculated to minimize variance as in ordinary least squared regression and thus the R-squared statistic for the two methods are not directly applicable (UCLA, 2011). Different methods can be used to produce the pseudo R-squared statistic. Stata, the program used for this analysis, utilizes McFadden's adjusted method to estimate the pseudo R-squared. That approach tends to produce lower pseudo R-squared estimates than other methods and can even take on negative values. 